\title{
The Risks for ASEAN of New Mega-Agreements that Promote the Wrong Model of e-Commerce
}

\author{
Jane KELSEY* \\ The University of Auckland, New Zealand
}

\begin{abstract}
October 2017
Digital technology offers exciting new opportunities and advances for ASEAN member states, individually and as a region. The benefits have so far been captured by first movers, especially in the United States. ASEAN countries need time and flexibility to develop their own digital industrialization strategies that can harness the potential gains and minimize the risks, and regulate accordingly. This paper explains how that opportunity would be foreclosed by a new normative framework on electronic commerce and cross-border services that is being systematically advanced by developed countries on behalf of their globally dominant digital industries. Starting with the Trans-Pacific Partnership Agreement, the template is being promoted through a network of mega-regional trade and investment agreements, including the Regional Comprehensive Economic Partnership and potentially the World Trade Organization. Instead of delivering a digital dividend to ASEAN countries, this model of ecommerce could impede their development, create negative fiscal and employment consequences, and leave them dependent on an oligopoly of private corporations that control the global digital infrastructure and mass data. ASEAN member states will need to resist those proposals if they are to maintain their regulatory sovereignty and the policy space to capitalize on the 21 st century digital revolution.
\end{abstract}

Keywords: e-commerce, ASEAN, mega FTAs, WTO, RCEP

\footnotetext{
* Faculty of Law, The University of Auckland, New Zealand. Email to J.kelsey@auckland.ac.nz
} 


\section{Introduction}

The world of digital economies, innovation, and global value chains (GVCs) is changing extremely rapidly. Every day there are stories about new technologies, services, and products that present unexpected possibilities and unforeseen challenges. There is potential to harness these innovations to revolutionize development across ASEAN, especially through regional initiatives that support its small and poorer members. If ASEAN countries are to maximize these opportunities, they will need international, regional, and national rules that facilitate digital industrialization, close the digital divide, and correct the development asymmetries that currently favour developed countries and their corporations. The wrong rules will deny them those benefits.

This paper examines how a systematic strategy of norm-creation through new generation mega-trade and investment agreements could embed the current asymmetries for the indefinite future. The novel chapter on electronic commerce in the Trans-Pacific Partnership agreement (TPP) is largely mirrored in the draft e-commerce annex of the Trade in Services Agreement (TiSA), the terms of reference for the Regional Comprehensive Economic Partnership (RCEP), and Japan's new bilateral free trade agreements (FTAs), including with the European Union $(\mathrm{EU})^{2}$. The EU has taken over from the United States (US) in driving the multilateralization of that template, pushing for a negotiating mandate on electronic commerce at the 11th ministerial conference of the World Trade Organization (WTO) in Buenos Aires in December 2017 (MC11).

The new e-commerce regime is not about 'free trade' and barely about real commerce. As with the WTO's Agreement on Trade-Related Aspects of Intellectual Property Rights (TRIPS), it aims to protect and entrench the oligopoly of first movers. Achieving a development dividend through digital industrialization, especially for small and poor countries, requires a collective commitment to local investment and shared knowledge. Instead, the proposed new global norms would consolidate the dominance of the technology giants over digital technologies, infrastructure, services, and - above all - data, the new oil of the 21 st century. ASEAN economies risk being locked into a state of dependency that some are describing as digital colonialism (Knowledge Commons, n.d.; Chaudhary and Moglen, 2017).

\footnotetext{
${ }^{2}$ The notable difference is the failure of the parties yet to agree on rules relating to cross-border movement of data.
} 
There are fiscal consequences too: a permanent ban on customs duties for economic transmissions could seriously deplete government revenues, while de-territorialization will foster the tax avoidance practices of companies like Google, Amazon, and Uber. Restrictions on the ability to regulate the digital domain also threatens non-economic imperatives of consumer welfare, economic stability, national security, privacy, and other citizens' rights. There is no special and differential treatment in these agreements, nor any genuine development flexibilities that might redress their imbalances, aside perhaps from the RCEP.

This paper begins by outlining the demands of the US digital industry that the Office of the United States Trade Representative (USTR) has adopted in its 'Digital2Dozen' agenda, and subsequently in the TPP. Their promotion of binding international rules appears to be in response to developing countries' moves to regulate the unregulated digital domain, and a growing competitive challenge from China. Section 2 outlines some of the development concerns arising from these rules. The third section outlines the potential for ASEAN members to be exposed to these proposed new norms through agreements they are currently negotiating. That is followed by a more detailed review of the legal obligations on crossborder services and e-commerce in the mega-agreements, and the weakness of protections for consumers, citizen rights, privacy, and national security. The final section reflects on the implications of these mega-agreements for ASEAN members who want to advance their national and regional development through digital industrialization. As of 2017, they are still in a position to adopt such strategies, individually and collectively. However, the paper warns that they will need to vigorously defend that policy space in their current and future negotiations.

\section{The US Demand for Rules}

Since the genesis in the US in the 1970s, the US government has insisted that the Internet remains a regulation-free zone. Discussions on Internet governance in the International Telecommunications Union (ITU) and the United Nations have been strongly resisted (Singh, 2017:11). ${ }^{3}$ Instead, the international regime has developed to reflect US domestic

\footnotetext{
${ }^{3}$ Singh reports that India proposed to the UN General Assembly the creation of a Committee for Internet Related Policies, with a mandate similar to the OECD committee. But this was rejected by the US and other countries as a move towards governmental control of Internet.
} 
law, which regulates telecommunications and protects the Internet from regulation. ${ }^{4} \mathrm{~A}$ private informal system of global Internet 'stakeholder' governance has emerged that is dominated by the major players, while the technical body that allocates domain names is controlled by a private company based in Los Angeles and governed by US law (Singh, 2017: 8-10). ${ }^{5}$ Far from creating a level playing field, this has allowed giant American firms (symbolized by the acronym GAFA - Google, Apple, Facebook, and Amazon) to establish control over the digital technologies that will drive the world's economies and societies in the coming decades - at least until some new technology that they do not control makes them redundant.

\subsection{The Digital Industry's Demands}

Ten years ago, the world's five largest companies by market capitalization were Microsoft, Exxon Mobil, General Electric, Citigroup, and Shell Oil. In 2017, they are Apple, Alphabet (parent company of Google), Amazon, Microsoft, and Facebook (PWC, 2017). According to Forbes magazine, 15 of the world's 25 largest tech companies in 2017 were from the US, including 8 of the top 10: Apple, Microsoft, Alphabet, IBM, Intel, Cisco Systems, Oracle, and Facebook (Stoller, 2017). South Korea's Samsung was the only nonUS firm in the top five. The world's top three Internet companies - Amazon (e-commerce), Google (search engine), and Facebook (social media) - were American, although the next two largest were from China: Tencent (social media) and Alibaba (e-commerce) (Deutsche Welle, 2016).

Specific segments of the market are highly monopolistic: in 2017, Google had an $88 \%$ market share in search advertising, Facebook controlled $77 \%$ of mobile social traffic, and Amazon had a 74\% share in the e-book market (Taplin, 2017). Their priority has been to increase their global market share. Sometimes they achieve this through loss-leading behaviour that undercuts competitors in the short term, as Amazon has been attempting in

\footnotetext{
${ }^{4}$ The stated goals of the US Telecommunications Act of 1996 (Code 47 U.S.C. $\$ 230$ (b)) were to 'promote competition and reduce regulation in order to secure lower prices and higher quality services for American telecommunications consumers and encourage the rapid deployment of telecommunications technologies' but to 'preserve the vibrant and competitive free market that presently exists for the Internet and other interactive computer services, unfettered by Federal or State regulation'.

${ }^{5}$ The Internet Corporation for Assigned Names and Numbers (ICANN).
} 
India (Peermohamed, 2016). ${ }^{6}$ Sometimes they buy up competitors and rising stars. ${ }^{7}$ The technology is the driver, not the sector. Google no longer just operates search engines; it is now testing fully driverless cars (Waymo, 2017). Amazon owns aircraft and airstrips, and has just patented a drone delivery system using parachutes to drop parcels on the doorstep (Levy, 2017).

These and other first movers who own the intellectual property (IP) and data, control the platforms and markets, and dominate the multi-stakeholder forums of Internet governance hold a massive advantage. Their industry groups have intensively lobbied the Obama administration, and later the Trump administration, to secure global rules that prevent national governments from regulating digital technologies, services, and products in the future (Internet Association, 2017). ${ }^{8}$ A revolving door between the industry and the Office of the USTR has helped them. Robert Holleyman, who became the deputy USTR from 2014 to 2017 and led the Digital Trade Working Group, has spent 23 years as President and CEO of BSA/Software Alliance (Crowell Moring, 2017). Former USTR and US Ambassador to the WTO Michael Punke was appointed Vice-President Public Policy at Amazon in 2016 (Behsudi, 2017).

The absolute priority for the major tech corporations is their right to control data, decide where in the world it is held and under what laws. Data is immensely valuable, financially and strategically. It can earn vast sums from advertising and be sold to private interests for commercial or personal purposes. It is the raw material used to analyse and influence social trends and shape public opinion by manipulating the content that individuals can see. Control over data can be abused by corporations and secured by the state to invade privacy, conduct surveillance, or cause tangible harm to individuals, businesses, and other governments. Equally, it can be censored by providers or governments for commercial or political reasons. Offshoring of data makes it extremely difficult to monitor compliance with privacy, consumer, or tax laws, let alone to enforce them. The status of financial data is

\footnotetext{
${ }^{6}$ In 2016, it was revealed that Amazon was prepared to absorb vast losses from investing US\$5 billion to become the top e-commerce site in India, and expanding into the lucrative entertainment sector.

${ }^{7}$ Google bought YouTube in 2006, Facebook's subsidiaries include Instagram, WhatsApp, and Messenger.

${ }^{8}$ An open letter to the USTR, October 2016, from seven groups that encompass all the major players: Internet Association, Computer and Communications Industry Association, Information Technology Industry Council, BSA/Software Alliance, ACT/The App Association, Consumer Technology Association. The industry also wanted a chief digital trade negotiator appointed in Office of USTR and to expand USTR's Digital Trade Working Group established in 2016 (USTR, 2016b).
} 
especially sensitive, as regulators require immediate access at a time of financial crisis or institutional collapse. ${ }^{9}$

Other industry demands include unrestricted rights to supply services across the border and a ban on requirements that cross-border suppliers have a local presence or that firms who are present in the country use local content or computer facilities. Technology transfer requirements should be prohibited, including obligations to disclose source codes for algorithms, apps or 'smart' products.

\subsection{The US 'Digital2Dozen'}

Since 2010, the US has promoted the industry's agenda in multiple international fora (OECD, 2014; G7, 2016; EU, 2017). In 2016, the USTR encapsulated them in what it called the 'Digital2Dozen' principles (USTR, 2016). These principles are carefully couched in the language of freedom and choice versus barriers, discrimination, and forced technology transfers or location:

1. promoting a free and open Internet

2. prohibiting digital customs duties

3. securing basic non-discrimination principles

4. enabling cross-border data flows

5. preventing localization barriers

6. barring forced technology transfers

7. protecting critical source code

8. ensuring technology choice

9. advancing innovative authentication methods

10. delivering enforceable consumer protections

11. safeguarding network competition

12. fostering innovative encryption products

13. building an adaptable framework for digital trade

14. promoting cooperation on cybersecurity

15. preserving market-driven standardization and global interoperability

16. eliminating tariffs on all manufactured products

17. securing robust market access commitments on investment and cross-border services, including those delivered digitally

18. ensuring faster, more transparent customs procedures

19. promoting transparency and stakeholder participation in the development of regulations and standards

20. ensuring fair competition with state-owned enterprises

21. promoting strong and balanced copyright protections and enforcement

\footnotetext{
${ }^{9}$ Financial data was not covered in the TPP. The e-commerce chapter in the EU-Japan FTA does not exclude financial services, but Article 6 in the Financial Services Chapter has square brackets.
} 
22. advancing modern patent protection

23. combating trade secret theft

24. recognizing conformity assessment procedures.

These principles formed the basis of the first comprehensive chapter on electronic commerce and new restrictions on a government's ability to regulate cross-border, financial, and telecommunications services in the TPP. The USTR described it as 'the most ambitious and visionary Internet trade agreement ever attempted' (USTR, 2016a). The TPP text set the template for TiSA, which was well advanced before negotiations were suspended in November 2016. ${ }^{10}$ The same demands informed the US 'non-paper' tabled in the WTO in July 2016 (WTO, 2016).

\subsection{Digital colonialism}

The US initiative gained momentum as developing countries began to regulate Internet activities (ITIC, 2016). The US strategy follows a familiar historical pattern: rich and powerful countries make 'global' rules that are presented to the developing world as a fait accompli. Trade agreements are co-opted as vehicles through which to develop binding rules that benefit the first movers. The digital industrialization strategies of later adaptors, and regulations designed to protect their strategic and social interests, are decried as 'market access barriers', 'discrimination', 'forced localisation', or 'digital protectionism' (ITIC, 2016). In a paper prepared for the South Centre, Parminder Singh observes how ...

In the emerging global digital order, developing countries, with the exception of China, are pushed to the periphery even more than in the traditional geo-economic arenas. A handful of nodes or centres, almost all of them in the US, control global networks of digital intelligence. Going by current trends, the level of structural dependency of developing countries in the digital society context is evidently going to be higher than ever. The phenomenon has also been called digital colonisation. (Singh, 2017: 6)

This reality belies the notion that ASEAN countries and their firms, let alone their small and medium-sized enterprises (SMEs), might leapfrog the industrial development process and become significant players in the global cross-border commerce (South Centre, 2017a). The barriers they face are set to intensify, unless they can develop effective national,

\footnotetext{
${ }^{10}$ TiSA, Annex on Electronic Commerce, undated (November 2016), http://www.bilaterals.org/?tisadraft-annex-on-electronic-32465
} 
regional, and global regulation. The US tech industry is pushing for global rules to pre-empt such regulation.

\subsection{The China Challenge}

The other main impetus for the US to develop these rules was the challenge to its ascendancy from China, whose outreach into Asia and Africa threatens the US's strategic and commercial objectives and the continued dominance of the US tech industry.

China has embarked on a systematic programme of digital catch-up. It has developed local platforms and markets by strategically blocking its competitors, supported by requirements for joint ventures and technology transfer (Dragoo, 2017). Government agencies are required to use national cloud services. The 'Made in China 2025' strategy aims to create the world's largest industrial robot market (Ma, 2017).

China's vision for cross-border e-commerce and Internet regulation is integral to the One Belt, One Road (OBOR) strategy to reestablish its historical trade routes (Greiger, 2016). The 'digital Silk Road' component of OBOR is closely tied to the internationalization of its largest digital operator, Alibaba. Alibaba's founder and executive chair Jack Ma describes his strategy as creating an 'ecosystem' that builds 'the fundamental digital and physical infrastructure for the future of commerce, which includes marketplaces, payments, logistics, cloud computing, big data and a host of other fields'. Ma's idea for an Electronic World Trade Platform (eWTP) centres on the establishment of digital free trade zones within and outside China (EUSME, 2016). Alibaba's first offshore venture is a Digital Free Trade Zone in Malaysia in collaboration with the state-owned Malaysia Digital Economy Corporation, announced in March 2017 (Alibaba, 2017). Ma claims this model will facilitate small businesses and there is some evidence of that; he contrasts this to "pure-commerce players' whom he predicts will face major challenges (Ma, 2016). However, Alibaba retains strategic control of the platform and data in its 'eco-system', which is where the real value lies (Transport Intelligence, 2016). In that sense, China's strategy is as self-interested and anti-competitive as the US.

There are additional tensions around the extent of state regulation. China's digital industrialization initiatives have been accompanied by a goal, announced in the 12th Five Year Plan in 2011, to strengthen regulation of the Internet (Dragoo, 2017). The new

Cybersecurity Law passed in November 2016 includes mandatory data storage inside China and data retention regulations. As Dragoo points out, China has framed Internet regulation as a matter of national security. That law effectively neutralizes competing considerations 
of consumer rights and privacy. The US has lodged and won several disputes at the WTO relating to censorship (e.g. WTO, 2009), but these were driven by commercial interests, not by principle. A US pro-industry think tank attacked China's new Cybersecurity Law as a 'vehicle for mercantilism' (Cory, 2017: 5-7). Yet the Chinese market is sufficiently attractive for big players to comply; for example, Apple has built an iCloud data centre in a joint venture with a local company (Dragoo, 2017) and agreed to remove from its hardware the VPN apps that are used to disguise the location of the user (Al Jazeera, 2017).

China is not averse to international rules on digital trade; it chaired the G20 when it adopted a broad list of principles on digital trade in 2016 (G20, 2016). But it does not support the US-led model. In a paper tabled in the WTO in late 2016 (WTO, 2016c), China argued for a gradual approach within the existing mandate of the working group on electronic commerce, which was set up in 1998 to discuss the issue. It cited Jack Ma's eWTP as a possible pathway, which embodied 'the spirit of solidarity' that can benefit developing countries and their SMEs. To avoid polarization, WTO members should prioritize the 'easy issues' of promotion and facilitation of cross-border trade in goods and support services, such as payment and logistics services.

China's approach is clearly distinct from the US-led model, and it presents as prodevelopment and supportive of SMEs (Shuiyu et al., 2017). But it carries a parallel risk for ASEAN that Alibaba and its affiliates will control Asia's regional infrastructure, platforms and data, and become the gatekeeper for ASEAN countries wanting to harness new technologies and value chains for development.

\section{Development Implications of this Model}

Concerns about the potential development implications of the US-led agenda have grown since the draft e-commerce annex for TiSA was first leaked (Our World Is Not for Sale, 2014), followed by the release of the final TPP text in November 2015. While the main focus has been on the economic development implications, sensitive questions of government constraints on freedom of speech and inadequate protections for privacy and consumer rights also need to be addressed. 


\subsection{Digital industrialization policies}

Latecomer developing economies require coherent digital industrialization strategies. Catch-up policies include targeted investment in domestic infrastructure, technology and $\mathrm{R} \& \mathrm{D}$; domestic preferences in public procurement; and technology transfer and joint ventures as a quid pro quo for market access and foreign investment. Domestic capabilities can be enhanced by requiring digital firms to have a local presence, store and process data locally, and use local computing facilities and infrastructure once they have been developed. Small and least-developed countries that cannot become self-sufficient may look to regional and cross-border collaborations for support that are not driven by purely commercial imperatives.

Various ASEAN members have already adopted one or more of these strategies. Many of those strategies would be unlawful under the mega-agreements. The US Information Technology Industry Council (ITIC) presents an annual catalogue of complaints to the USTR. Its 2016 submission targeted the practices of four ASEAN countries: Viet Nam, Indonesia, Malaysia, and the Philippines (ITIC, 2016).

\subsubsection{Viet Nam (ITIC, 2016: 22-23)}

- Vietnam's Decree on Information Technology Services 2013 requires every digital service or website to locate at least one server in Viet Nam.

- A new draft decree on the use of Internet Services and Online Information gave only a 3hour window for compliance with content takedown requests. ITIC said that deviates from international standards on intermediary liability frameworks.

- ITIC objected to additional 'long and inflexible' data retention requirements, local presence requirements for foreign game service providers, requirements to interconnect with local payment support service providers, and 'other market access barriers'.

- The Law on Network Information Security appeared to require source code disclosure of encryption software, encryption key surrender and the transfer of proprietary trade secrets of cybersecurity products.

- The requirement to obtain licences to sell products within Viet Nam could be implemented in a discriminatory way.

- The Decree Guiding Law on Cyber Security imposed broad import-export and business licensing and certification requirements on various ICT products that had cryptographic capability and strict local presence requirements for providing cybersecurity services. 
- A draft IT services decree would have included additional data localization requirements and restrictions on cross-border data flows that had been shelved, but ITIC noted suggestions it was being reconsidered.

- Many of these policies would be prohibited under the TPP.

\subsubsection{Indonesia (ITIC, 2016: 15)}

- The Draft Regulation Regarding the Provision of Application and/or Content Services Through the Internet (2016) was said to impose 'vague requirements', such as 'must place a part of its servers at data centers within the territory of the Republic of Indonesia'.

- Indonesia's regulations require localization of data centres and disaster recovery centres, disclosure of source code for software developers, and other costly obligations.

- The new patent law requires foreign patent holders to transfer proprietary technologies to local companies and to make the product or use the process in Indonesia.

- Strict local content rules are being phased in on new smartphones, laptops, etc.

- Proposed tax measures conflict with the multilateral principles ${ }^{11}$ of the Organisation for Economic Co-operation and Development (OECD) and would compel foreign services to create a permanent establishment in Indonesia in order to do business and undertake a rigorous process of registration.

- The local presence requirements would likely violate Indonesia's commitments to the General Agreement on Trade in Services (GATS) to allow computer and related services to be provided on a cross-border basis.

- Investment in and importing of mobile phones were being relaxed but direct sales to consumers were still prohibited.

\subsubsection{Philippines (ITIC, 2016: 18)}

- A draft administrative order in 2014 required government agencies to buy cloud services from the Philippine government's cloud.

- Other government procurement preferences generally favour local companies and locally produced materials and suppliers.

- Telecom regulators have interpreted existing regulations to mean cloud service providers must obtain a Value-Added Telecom Services licence, which is open only to Filipino

\footnotetext{
${ }^{11}$ Indonesia is not a member of the OECD.
} 
companies. While that has not been consistently enforced, it will be severely limiting if it is.

\subsubsection{Malaysia (ITIC, 2016: 16)}

- Malaysia was proposing to include regulation of online services within the jurisdiction of its communications regulators. ITIC urged the USTR to respond by promoting a 'lighttouch framework' for regulating information services.

- Malaysia should be encouraged to avoid creating market access barriers by subjecting foreign Internet services and applications to telecom-specific or public utility regulations.

ITIC argues that these rules damage the interests of the host countries as well as their own businesses by restricting state-of-the-art technology and services, cost efficiencies, and consumer choice. Moreover, foreign firms might bypass those countries if such regulations were imposed. However, the self-interest of ITIC needs to be separated from genuine development arguments. Doing so requires a systematic and independent assessment that balances the anticipated benefits against the costs and risks, such as those outlined below.

\subsection{Anti-competitive practices}

'Competition' was among the new issues proposed and rejected at the WTO ministerial conferences in Singapore in 1996 and Cancun in 2003. The developed country proponents wanted rules requiring domestic competition. Developing countries said the real problem was the oligopolistic dominance and cartel-like behaviour of transnational corporations, which requires competition rules at the global level (Khor, 1996).

The same arguments have resurfaced with the digital economy. The demand for a level playing field within countries belies the global concentration of corporate power. Competition may appear to occur at the retail or consumer end, but there is a near monopoly or cartel among those who control the digital platforms and outlets. Reflecting on the 'problem of bigness' from a development perspective, Sabeel Rahman observes that: 'Users are locked into a single platform, which then leverages this user base and vast store of underlying data to grow even bigger, colonize adjacent markets, and eventually, once other competitors are no longer a threat, raise prices' (Rahman, 2016: 7). Or as Peter Thiel, founder of PayPal, Facebook board member, and adviser to the Trump administration, admitted frankly: 'monopoly is the condition of every successful business (Thiel, 2014). 
The concern that dominant Internet service providers (ISPs) can block access by others, prioritize content, and lower the speed for or extract rent from competitors is central to the net neutrality debate. In 2015, the US Federal Communications Commission (FCC) recognized that ISPs were so dominant that consumers had no real choice, and it reclassified the providers as telecom firms that are subject to common carrier requirements. The Trumpappointed head of the FCC has promised to reverse that decision (Shepardson, 2017). In mega-agreements, net neutrality is subject to 'reasonable network management', ${ }^{12}$ which the providers are left to define.

Rahman suggests three options that, in theory, could counter these anti-competitive practices. All options would be difficult for many ASEAN countries, and some would be unlawful under the mega-agreements:

(i) Some governments, notably the EU, have tried to impose their internal competition law on the big players. Microsoft faced and lost an anti-competition case in the EU in 2007 (Microsoft Corp v Commission, 2007). In June 2017, Google was fined 2.4 billion euro by the EU Competition Commission for a complaint that the company was unfairly promoting its own in-house services. Google was given 90 days to comply or face a significant additional fine of $5 \%$ of global daily revenues (EC, 2017). ${ }^{13}$ However, such inquiries are long and costly; the Google complaint dated back to 2010. Most ASEAN countries would have to depend on developed states with more sophisticated competition regimes and more resources to challenge such behaviours, and hope that successful outcomes applied globally.

Competition law might also be used to impose restrictions on predatory behaviour (Peermohamed, 2016) ${ }^{14}$ and the consolidation of market power through mergers and acquisitions (Sen, 2017). ${ }^{15}$ However, even if that challenge succeeded, the size and resources of the major players mean that only other large players could compete in the long term, especially on a cross-border scale.

(ii) The dominant players could be treated as natural monopolies in their market segments and regulated as public utilities, as telecommunications usually are. They could then be

\footnotetext{
12 TPP, Article 14.10(a).

${ }^{13}$ Independent assessments found that $91 \%$ of 25,000 random searches on Google put Google products in the top slot.

${ }^{14}$ In 2016, it was revealed that Amazon was prepared to absorb vast losses from investing US\$5 billion to become the top e-commerce site in India, and expanding into the lucrative entertainment sector.

${ }^{15}$ Amazon's main competitor, Indian-owned Flipkart, received a US\$1.4 billion investment from Microsoft, Tencent, and eBay, with a possible merger with Snapdeal, India's third most popular online retailer.
} 
required to share technologies, and license out search algorithms, advertising exchanges, and other key innovations for a nominal fee (Taplin, 2017). The mega-agreements would prohibit such measures.

(iii) Governments could conclude that market competition is insufficient incentive for competitors to build infrastructure, and establish a government-chartered entity to provide the service direct to the public. This presumes a country (or regional arrangement) has the necessary funding, technological capacity, access to proprietary knowledge, including source codes, and trained local personnel - none of which can be required under the mega-agreements. This option might also fall foul of new disciplines on state-owned enterprises. ${ }^{16}$

\subsection{Foregoing benefits of foreign direct investment}

There are various development rationales for foreign direct investment, although they are not always achieved. Governments expect to improve access to and transfer of technology, strengthen domestic firms and state-owned enterprises through joint ventures, develop shared $R \& D$, build managerial skills and train workers. They also aim to secure new export channels and efficiency gains through competitive pressures on local companies. Those opportunities are largely lost by requirements to allow foreign firms to supply services across the border, and prohibitions on requiring them to have a local presence, use the local facilities the country has invested in establishing, employ local people if they would gain access to proprietary knowledge, or transfer technology. While cross-border services might provide better quality, providers lack the commitment to maintain supply that would come with sunk investment and the country's long-term dependency would intensify.

\subsection{Global value chains}

Research suggests that most integration of developing countries into global value chains (GVCs) since the ICT revolution of the 1990s is through cost-driven outsourcing, which does little to reduce the underdevelopment of host countries (Azarhoushang, et al., 2015: 164). The value-added usually stays in the parent country, with locally earned profits repatriated through complex legal and accounting arrangements. In recent times, procurement sources in GVCs have become more fluid. That can benefit ASEAN

\footnotetext{
${ }^{16}$ TPP, Article 17.4: Non-discriminatory treatment and commercial considerations, and Article 17.6: Non-commercial assistance.
} 
economies, and even SMEs, provided they can compete. At the same time, the constant churning of commercial relationships also creates unpredictability and instability. ${ }^{17}$

Moreover, those seeking to access international platforms or e-marketplaces to sell products must negotiate with the aggregator, such as Google or Amazon. Amazon dominates e-book and online print sales in the US and its subsidiary Audible.com is the primary supplier of Apple's iTunes audio book store (Author Earnings, 2016). Sellers lack negotiating power and remedies. In one documented case, books of a company in dispute with Amazon over commissions disappeared off the site, shipment times were delayed, and searches for authors were redirected to works of other publishers (Thomson, 2017).

As part of its anti-trust inquiries, the EU found increased use of contract restrictions to control product distribution (Fioretti, 2017). Big manufacturers are using selective distribution systems where products can be sold only by pre-authorized sellers, which gives the manufacturers more control over distribution, price, and brand image. Almost half the manufacturers using selective distribution systems blocked pure online retailers, such as eBay, from selling their products. eBay has complained that such bans prevent small businesses from selling products on online marketplaces. No tools in the agreements constrain these practices, and moves to do so could breach the disciplines on domestic regulation of technical standards for services or the administration of general regulations (discussed below).

\subsection{Artificial intelligence}

Rapid advances in artificial intelligence (AI) have economic, social, and political implications. China-based Taiwanese venture capitalist Kai-Fu Lee predicts intense concentrations of wealth in the relatively few hands of those who control the complex AI technology (Lee, 2017). A multiplicity of rules in the mega-agreements - from source code secrecy and bans on technology transfer to unrestricted cross-border supply of services and financial flows - would constrain the development of local AI and its regulation.

Lee observes that 'strength begets strength'. He predicts that dominant players will move to capture AI in other countries, with the US dominating developed markets and China, the developing markets. Many jobs will be eliminated and not replaced, especially low-wage jobs that are currently created through offshoring of production and services. That

\footnotetext{
${ }^{17}$ Seven of India's IT firms reported 58,000 layoffs in 2017 as growth in the industry slows, companies seek fresh low-cost labour, automation displaces workers, and US politics affects IT industry policy; see (Sood, 2017).
} 
is especially problematic for developing countries that will have growing populations, but fewer jobs. Lee underscores the paradox that managing this economic (and political) liability will require Keynesian-style transfers through increased taxation and redistribution, but the money made from AI will be transferred to the US and China.

\subsection{Digital products}

The scope of e-commerce has expanded from the delivery of tangible goods ordered through the Internet to electronically transmitted products and production through remote additive manufacturing (RAM), such as 3D printing. Rashmi Banga calculates that six countries have captured more than $85 \%$ of the e-services market that would deliver these digital products: China (40\%), US (20\%), the United Kingdom (9\%), Japan (5\%), Germany (4\%), and France (4\%) (Banga, 2017). Unrestricted rights to supply services across the border would entrench the dominance of, and structural dependency on, those suppliers and make it extremely difficult for firms in developing and small countries to participate meaningfully in international markets.

There would also be significant impacts on traditional manufacturing. The huge reduction in manufacturing costs and the ease of relocation mean that competitive advantage will shift from high-volume low-cost manufacturers to owners of customer networks. Banga suggests the future for SMEs is especially bleak. She argues for a digital industrialization strategy and regulatory framework that can realistically address these challenges. That needs to be accompanied by improved Internet penetration, strengthening of national trade portals, improving the capacity of postal services, and strategic action plans to boost cross-border ecommerce. These steps require ASEAN countries to retain their policy space.

\subsection{Fiscal and tax impacts}

Tax authorities already struggle with the tech giants' complex global corporate structures. It is even more problematic to tax cross-border transactions and profits earned in a country when local presence is absent in that country. Tax exceptions in the megaagreements are complex and variable. ${ }^{18}$

The new rules pose a second fiscal challenge. A temporary moratorium on customs duties on electronic transmissions at the WTO is renewed every 2 years. It was first agreed

\footnotetext{
${ }^{18}$ For example, Article 14.3 of the TPP preserves the right to impose internal taxes on electronically transmitted content, provided they are imposed in a manner consistent with the agreement. Article 29.4 is a complex provision that excludes tax from the agreement, subject to various carve-ins.
} 
in 1998, when the current scale of coverage was unforeseen by most members (WTO, 1998). The new regime would ban those duties permanently. Banga conducted a tariff simulation analysis that projects serious revenue impacts for ASEAN countries as net importers of electronically transmitted products, especially for Viet Nam, Thailand, Philippines, Indonesia, and Cambodia (Banga, 2017: 13, Tables 3, 4, and 17).

Governments could eventually lose customs duties for most non-agricultural manufactured products if the ban extends to cross-border transmissions of RAM, for example, the cross-border transfer of 3-D printing specifications for products that are then printed inside the country. The loss of tariff revenues and/or damage to domestic competitors would be huge. Developed countries that already have minimal or zero tariffs would be unaffected. Falling revenue would deprive ASEAN countries of the investment required for effective digital industrialization strategies and to address the impacts on local businesses, employment, and communities.

An additional concern is the link between the customs duty moratorium and a moratorium on non-violation nullification and impairment disputes under TRIPS, which the US demands as a quid pro quo (Patnaik, 2015). If the current trade-off goes, developing countries may have to concede something else to secure renewal of the TRIPS moratorium.

\subsection{Safety, security, and citizens' rights}

Businesses, households, communities, and governments are already heavily reliant on Internet search engines, digital platforms, websites, apps, and social media. That carries significant risks. Examples in the past year show how an ISP outage (Fung, 2017), faulty software or technical maintenance (Buck and Hollinger, 2017), or the installing of malware (BBC, 2017; Monaghan, 2017) ${ }^{19}$ can bring banking and payment systems (Reuters, 2017), an airline (Buck and Hollinger, 2017), railway (Times of India, 2017), and large parts of the global supply chain ${ }^{20}$ (Gonzalez, 2016) to a halt. Safety and security risks associated with artificial intelligence, such as drones, robots, and driverless vehicles, will also intensify as other, as-yet-unimaginable technologies evolve.

Foreign states and private actors have even intervened in other nations' electoral processes and created mayhem through politically motivated cyber-attacks (New York Times, 2017). There is greater awareness of the scope for commercial and political

\footnotetext{
${ }^{19}$ The Wannacry attack in May 2017 affected 99 countries.

${ }^{20}$ The NotPetya cyberattack in June 2017 disrupted the supply chains of major manufacturers like Reckitt Benckiser, affecting the production of their suppliers.
} 
espionage and sabotage, including by foreign governments. Citizens of other countries could be subject to legalized corporate and state surveillance, depending on where their data is located - something over which they have no control. People's fundamental human rights are at risk from censorship of providers, sites, and content by the user's home or host state, or by ISP and platform operators (UN, 2016). These restrictions can also nullify the economic and social benefits of widespread connectivity (Khan, 2009).

The mega-agreements subordinate these considerations to the commercial interests of the industry and, as a later sector explains, the protections and exceptions are ineffectual where they are provided.

\section{Negotiating Challenges for ASEAN}

No ASEAN countries are currently subject to these rules, although Brunei Darussalam, Malaysia, Viet Nam, and Singapore will be if the TPP comes into force. However, all ASEAN members are parties to several negotiations in which similar proposals have been tabled.

\subsection{The Regional Comprehensive Economic Partnership}

In February 2015, the Trade Negotiation Committee (TNC) of RCEP endorsed a proposal to establish an e-commerce working group:

The TNC reiterated the importance and potential of e-commerce to economic development and enhanced GVCs, including for the SMEs. The TNC also highlighted the need to seek balance between commercial interests and legitimate public policy and regulatory objectives. Further, the TNC noted the different levels of regulatory capacity and readiness among the RCEP participating countries or RPCs with regard to e-commerce. Most RPCs welcomed the recommendation to establish a Working Group on e-Commerce while a few RPCs were of the view that domestic consultation is required (RCEP, 2015).

As Table 1 shows, the headings in the terms of reference for negotiations on e-commerce largely follow the TPP and TiSA template. 
Table 1: Comparison of TPP with Proposed Elements for RCEP Terms of Reference for e-Commerce*

\begin{tabular}{|c|c|c|c|}
\hline \multicolumn{2}{|l|}{ TPP } & \multicolumn{2}{|c|}{$\begin{array}{l}\text { RCEP Proposed elements for terms of } \\
\text { reference }\end{array}$} \\
\hline Article & Provision & $\begin{array}{l}\text { If yes: } \\
\text { Article }\end{array}$ & Provision \\
\hline 14.9 & Paperless trading & Y: II & Paperless trading \\
\hline 14.6 & $\begin{array}{l}\text { Electronic authentication and } \\
\text { electronic signatures }\end{array}$ & Y: II & $\begin{array}{l}\text { Electronic signatures and digital } \\
\text { certification }\end{array}$ \\
\hline 14.7 & Online consumer protection & Y: III & Online consumer protection \\
\hline 14.8 & $\begin{array}{l}\text { Personal information } \\
\text { protection }\end{array}$ & Y: III & Online personal data protection \\
\hline 14.14 & $\begin{array}{l}\text { Unsolicited commercial } \\
\text { electronic messages }\end{array}$ & Y: III & Unsolicited commercial email \\
\hline 14.5 & $\begin{array}{l}\text { Domestic electronic } \\
\text { transactions framework }\end{array}$ & Y: III & Domestic regulatory frameworks \\
\hline 14.3 & Customs duties & Y: III & Customs duties \\
\hline 14.4 & $\begin{array}{l}\text { Non-discriminatory } \\
\text { treatment of digital products }\end{array}$ & Y: III & $\begin{array}{l}\text { Non-discriminatory treatment of } \\
\text { digital products }\end{array}$ \\
\hline 14.13 & $\begin{array}{l}\text { Location of computing } \\
\text { facilities }\end{array}$ & $\mathrm{Y}: \mathrm{IV}$ & $\begin{array}{l}\text { Prohibition on requirements } \\
\text { concerning the location of } \\
\text { computing facilities }\end{array}$ \\
\hline 14.17 & Source code & Y: IV & $\begin{array}{l}\text { Prohibition on requirements } \\
\text { concerning the disclosure of source } \\
\text { code }\end{array}$ \\
\hline 14.11 & $\begin{array}{l}\text { Cross-border transfer of } \\
\text { information by electronic } \\
\text { means }\end{array}$ & $\mathrm{Y}: \mathrm{IV}$ & $\begin{array}{l}\text { Cross-border transfer of } \\
\text { information by electronic means }\end{array}$ \\
\hline
\end{tabular}

* Adapted from a table prepared by Sanya Reid Smith from Third World Network

The author's discussions with negotiators confirm that an e-commerce text has been tabled in RCEP that largely mirrors the TPP, with Japan as principal proponent. However, no information on the state of negotiations in this chapter is publicly available. 


\subsection{ASEAN negotiations with the EU}

ASEAN and several of its members have been or are negotiating FTAs with the EU, which is the world's largest exporter of digitally delivered services (Council of the EU, 2017: 1). ${ }^{21}$ Until recently, the EU was not a strong proponent of e-commerce rules in its agreements. Chapter 8 on Services, Establishment, and Electronic Commerce in the EUSingapore FTA from 2014 (not yet ratified) focuses on cross-border services. ${ }^{22}$ The preliminary text of the EU-Vietnam FTA, released in February 2016, has two significant obligations: it adopts the EU's Understanding on Computer and Related Services (discussed below) and Chapter VI on Electronic Commerce imposing a permanent prohibition on customs duties on electronic transmissions. Otherwise, the chapter just establishes a regulatory dialogue. Chapter 16 on e-commerce in the Comprehensive Economic and Trade Agreement between Canada and the EU (CETA) also has limited scope and obligations. There is no public information on the EU's approach to e-commerce in the FTA negotiations with Indonesia (European Commission, 2017a). ${ }^{23}$

The text of the EU-Japan Economic Partnership Agreement, released in July 2017, signals a significant shift for the EU. The chapter goes beyond the TPP in several respects, ${ }^{24}$ although the sensitive matter of cross-border data flows is unresolved due to an internal conflict in the European Commission over the right to privacy.

\subsection{Electronic commerce at the WTO}

The EU has also taken the lead in pressing for e-commerce negotiations in the WTO. In 1998, the WTO General Council agreed to a Work Programme on Electronic Commerce with a limited mandate to discuss the issues. The preamble recorded that the General Council would establish a comprehensive work programme to examine all trade-related issues associated with global electronic commerce, including those issues identified by members. The work programme would involve the relevant WTO bodies, take into account the economic, financial, and development needs of developing countries, and recognize that work is also being undertaken in other international fora. The General Council should submit a progress report and any recommendations for action at the Third Session of the Ministerial Conference (WTO, 1998). E-commerce was defined for the purposes of these discussions

\footnotetext{
${ }^{21}$ The EU estimates the global market in e-commerce is worth over 12 trillion euros.

${ }^{22}$ EU-Singapore Free Trade Agreement, signed in June 2015, Sub-section 3, Article 8.21 commits the parties to adopt the EU's Understanding on Computer Related Services, described above.

${ }^{23}$ The report of the second round of negotiations in January 2017 does not refer to e-commerce.

${ }^{24}$ For example, Chapter VI, Article 3 bans customs duties on electronic transmissions.
} 
as 'the production, distribution, marketing, sale or delivery of goods and services by electronic means' (WTO, 1998: para 1.3).

Since then, discussions have taken place across the Council for Trade in Goods, Council for Trade in Services, TRIPS Council, and the Committee on Trade for Development. Various reviews and reports were made, including to ministerial conferences. ${ }^{25}$ But there was little momentum until July 2016 when the US tabled a 'non-paper' setting out 16 demands, based on its 'Digital2Dozen' principles (WTO, 2016). The US has not actively intervened since then, presumably because its negotiating positions and relationship to the WTO are under review by the Trump administration. However, various statements indicate strong US support for TPP-style digital rules in future trade negotiations (Caporal, 2017).

The US may be happy to leave the WTO groundwork to the EU, Japan, and others. There has been a flurry of activity leading up to the MC11 in December 2017. Japan sought to 'reinvigorate' discussions on e-commerce around the same time as the US non-paper (WTO, 2016a; see also WTO, 2017). The EU and others tabled a comprehensive proposal in January 2017, but that faced strong push-back from many developing countries (WTO, 2017a). In May 2017, the EU strategically trimmed and relabelled its proposal 'facilitating on-line transactions' (WTO, 2017b). However, the 'trade facilitation' elements from its earlier paper included substantive rules that clearly form part of the EU's ultimate objectives (WTO, 2017a: 3).

Developing countries have taken divergent positions in the WTO and related discussions in UNCTAD (South Centre, 2017). A group of Friends of e-Commerce for Development, including several ASEAN countries, ${ }^{26}$ has supported negotiations in the hope that it facilitates economic growth and development, especially for MSMEs (WTO, 2017c). Interestingly, their workshop in April 2017 at the WTO was jointly hosted by the US National Foreign Trade Council Global Innovation Forum, as was a reception for the Director General of the WTO (GIF, 2017). The least developed countries (LDCs) have led the opposition, along with the Africa Group who objected that the proposals would undermine their regional development strategy for socio-economic transformation 'Agenda 2063' (WTO, 2017g, para 5.36). China's only tabled paper, from November 2016, did not support a new WTO mandate. It argued for a consensus approach to address a more limited

\footnotetext{
${ }^{25}$ These are accessible at: https://www.wto.org/english/tratop_e/ecom_e/ecom_e.htm

${ }^{26}$ Brunei Darussalam, Malaysia, and Singapore.
} 
agenda of customs duties and facilitation (WTO, 2016b), which is consistent with its One Belt One Road digital initiative.

At the time of writing ASEAN had not taken a firm position on a WTO mandate to negotiate. A non-committal communication in April 2017 noted that e-commerce was not new to the WTO and there was room for clarifying how new concepts fit (WTO, 2017d). While there were opportunities for MSMEs from lower cost barriers and greater inclusion, there were challenges from a lack of infrastructure and knowledge, limited e-payment options, regulatory barriers and uncertainty, limited access to enabling services, online privacy and security issues, gaining consumer confidence and ongoing digital divides. The paper observed that the development of facilitative trade rules could be supportive if that reduced regulatory uncertainty, and there was a role for international organizations and donor partners. ASEAN had set up a coordinating committee on e-commerce in November 2016 and was itself working towards an e-commerce agreement.

These various negotiating forums will require ASEAN to determine its position on the US-led model sooner rather than later.

\section{The New Legal Texts}

Every agreement has idiosyncrasies that reflect the parties and the power dynamics between them. Despite that, a common core of text is populating the contemporary megaagreements. It has a chameleon-like presence: the same provisions may appear in chapters on cross-border services, investment, e-commerce, intellectual property, and transparency. Most were re-categorized as services rules for the purposes of TiSA. The following elements therefore need to be viewed as a whole:

- cross-border services, whether committed in positive list schedules or subject to negative list annexes of non-conforming measures;

- electronic commerce;

- financial services;

- telecommunications services;

- intellectual property;

- investment performance requirements;

- localization requirements; 
- state-owned enterprises;

- customs duties on electronic transmissions;

- payments and transfers;

- balance of payments and prudential exceptions;

- the general exception; and

- the security exception.

A thorough discussion of all these elements is beyond the capacity of this paper. The following analysis centres on the cross-border services and electronic commerce chapters.

\subsection{Cross-border services}

The digital era has given services a new significance. The 'servicification' of economies dates back to the early 1970s when agricultural, mining, fisheries, and manufacturing production began splintering into chains of discrete services activities. Today, digital technologies have enabled those services to be supplied across the border in ways that were previously unimaginable. New services have also emerged, such as leasing cloud storage. The Internet of Things has integrated digital services into physical goods, such as smart cars and household appliances. 3D printers render production itself an IT service. Automated services such as robots and AI are replacing human labour on production lines, stores, and transportation.

A major goal of the mega-agreements is to future-proof services and technologies from regulation. Several complementary ways are used to achieve this.

\subsubsection{Classification of services}

The list used for classification of services known as W/120 (GATT, 1991) is based on a provisional UN Central Product Classification (UNCPC) that dates back to $1991,{ }^{27}$ about the time the worldwide web was invented. The descriptions that accompany the 160-plus subsectors are sometimes specific and sometimes vague; some even include an undefined sub-category of 'other'. ${ }^{28}$ The application of categories like computer and related services, telecommunications, business services, and financial services has expanded dramatically since 1991. There is an unresolved debate on whether and which new services may be captured by the old CPC list, and if so under which of several possible categories. Some

\footnotetext{
${ }^{27}$ https://unstats.un.org/unsd/cr/registry/regcst.asp?Cl=9\&Top=1\&Lg=1

${ }^{28}$ For example, CPC 84: computer and related services.
} 
agreements adopt new more detailed versions of the UNCPC, or other classifications, such as the International Standard Industrial Classification (ISIC), making it difficult to compare agreements.

\subsubsection{Computer and related services}

As part of the GATS 2000 round of negotiations, the EU proposed an Understanding on Computer and Related Services that sought to clarify coverage of technologies that enable the delivery of services (it did not want to revise the classification system itself) (WTO, 2002). ${ }^{29}$ The EU asked members to inscribe the understanding in their schedules. However, the GATS 2000 negotiations and schedules were never concluded. Adoption of the Understanding or its equivalent is now a standard requirement in the EU's FTAs. Making full commitments for all those computer and related services would potentially pre-commit governments to allow unrestricted cross-border provision of all digitally enabled services and never to impose measures such as preferences for locals, requirements for jointventures, or restrictions on the volume or market share of certain services. ${ }^{30}$

\subsubsection{Cross-border services}

Uncertainty about the classification of services is compounded by the unanticipated expansion of their cross-border delivery. When the GATS schedules were drafted in the early 1990s, the technologies to supply services across the border (mode 1) were usually by mail, fax, or telephone (Adlung and Roy, 2005: 12, chart 3). Most WTO members limited their exposure in mode 1 (although acceding countries were required to make more commitments). Rudolph Adlung and Martin Roy speculate that:

\footnotetext{
${ }^{29} 8$. Computer and related services, regardless of whether they are delivered via a network, including the Internet, include all services that provide:

- consulting, strategy, analysis, planning, specification, design, development, installation, implementation, integration, testing, debugging, updating, support, technical assistance, or management of or for computers or computer systems; or

- computer programmes defined as the sets of instructions required to make computers work and communicate (in and of themselves), plus consulting, strategy, analysis, planning, specification, design, development, installation, implementation, integration, testing, debugging, updating, adaptation, maintenance, support, technical assistance, management or use of or for computer programmes; or

- data processing, data storage, data hosting or database services; or

- maintenance and repair services for office machinery and equipment, including computers; or

- training services for staff of clients, related to computer programmes, computers or computer systems, and not elsewhere classified.

${ }^{30}$ The rules of trade in services agreements apply to 'measures that affect the supply of a service'.
} 
Members may have hesitated to undertake commitments under this mode out of uncertainty of the legal implications and perceived constraints on their ability to intervene later for regulatory purposes or employment-related and other strategic policy reasons ...

or to encourage delivery of services through investment in the country (2005: 12). That caution now seems justified. The provision of cross-border services has grown exponentially, both for the infrastructure of the digital economy, such as computer and related services, telecommunications, financial, transport and distribution services, and for specific sectors like audio-visual, tourism, education, and the professions.

Parties in the mega-agreements are under pressure to greatly increase their commitments on cross-border services, which may combine modes 1 and 2.

\subsubsection{Technological neutrality}

Under the concept of 'technological neutrality', commitments to allow the supply of a particular service would apply irrespective of the technology used to deliver that service even if the technology (such as drones and driverless vehicles) was inconceivable when the schedule was drafted and the government would not have made the commitment had it known. If accepted, the concept would consolidate the dominance of first movers, especially in sectors where governments have made unlimited commitments on the cross-border supply of services.

Developed countries treat the application of technological neutrality as a settled question and the WTO Secretariat has described it as 'the general view' of members (WTO, 1999: para 4). However, scholars acknowledge that the legal status of the concept is contested (Mattoo, 2000: 15-17; Hu, 2013: 86). Technological neutrality is not referred to in the GATS text. Nor is it mentioned in the scheduling guidelines (WTO, 2001). An interpretive note to the Reference Paper on Basic Telecommunications says commitments pursuant to that paper are technologically neutral (WTO 1998: para 8), which implies a difference from the rest of GATS. Explicit references to technological neutrality in later agreements could be read in several ways. For example, the EU-Japan FTA says the principle of technological neutrality applies to electronic commerce, ${ }^{31}$ but there is no equivalent statement in the cross-border services chapter. A reference in just one chapter could imply that the principle is not more generally applicable, or that a similar statement is deemed unnecessary for services.

\footnotetext{
${ }^{31}$ EU-Japan FTA, Article 1.3.
} 
The concept has been argued in WTO disputes and was not rejected as a possibility (WTO, 2004: para 6.285; WTO, 2009: para 7.1257); however, panels have not relied on it for their decisions. Even if they had, the Dispute Settlement Body has no power to interpret the GATS. The Agreement Establishing the WTO reserves that right to the members, who are divided on the issue. ${ }^{32}$

\subsubsection{Local presence}

It is common for mega-agreements to ban requirements that cross-border service suppliers have a local presence inside the country. ${ }^{33}$ That poses serious obstacles to receiving countries' ability to vet qualifications and assess compliance with technical and professional standards and consumer protections, as well as monitoring and enforcing the labour standards of workers who are delivering the service. Effective oversight and enforcement may become dependent on the laws of the country the services are supplied from, the cooperation of their regulators, affordable access to their legal systems, and their courts' willingness to accept jurisdiction. Lack of a local presence may also pose practical and legal obstacles for the state's ability to tax transactions and local earnings.

\subsubsection{Scheduling of commitments}

The GATS uses positive list schedules to record each WTO member's commitments not to use proscribed market access measures ${ }^{34}$ and not to discriminate in favour of domestic services and suppliers (national treatment). ${ }^{35}$ The schedule specifies which of the W/120 sub-sectors is subject to each rule, differentiating between modes of supply, and allowing limitations on any commitment in any mode. Developing countries insisted on this approach to maximize their control over their GATS commitments. Most subsequent FTAs involving ASEAN countries use positive list schedules.

The major services exporting countries and their commercial lobbies object that positive lists minimize countries' commitments and result in partial and fragmented coverage of their services operations. Three techniques have been developed in the mega-agreements to secure more extensive commitments and restrict the existing and future regulation of services, including services not yet created.

\footnotetext{
${ }^{32}$ For example, China has repeatedly rejected its application in the GATS disputes.

${ }^{33}$ That may be located in the services or e-commerce chapter; e.g. TPP, Chapter 10: Cross-border services, Article 10.6; TiSA, Localization Provisions, November 2016, Art X.1.

${ }^{34}$ GATS Article XVI.

${ }^{35}$ GATS Article XVII.
} 
(i) The negative list approach fully commits governments to all the relevant rules ${ }^{36}$ for all services and measures they do not expressly reserve. Reservations are usually listed in two annexes or schedules. One annex allows a party to specify existing measures that will not be subject to certain rules, but these measures cannot be made less-conforming (more restrictive) in the future (a 'standstill'). In some agreements, that annex is also subject to a 'ratchet', which automatically locks in any future liberalization. A second annex allows governments to explicitly preserve the right to maintain and adopt measures for specific sectors or activities that would otherwise contravene specified rules ('policy space' reservations). Both schedules must be negotiated with the other parties.

The Internet Digital Economy Alliance explains the benefits to the industry and risks to the governments: 'A negative list approach is much more future proof, but also means that countries must be comfortable with the idea that over time the commitments to liberalization they are making will expand automatically' (IDEA, 2013, page 3, fn 13). Put another way, a negative list forecloses the ability of a government to address policy, regulatory, social, or political failures, unless it had the foresight and negotiating strength to preserve the necessary policy space or can successfully invoke one of the agreement's exceptions (discussed below). This approach is high risk in legal and political terms, even for governments with a long experience of liberalization, privatization, deregulation, and market-based regulation, and which have well-resourced bureaucracies and experienced negotiators.

(ii) The hybrid approach has several variations:

- TiSA uses a hybrid of a positive list for market access and a negative list for national treatment and other 'anti-localization' rules.

- The parties to the Indonesia-Japan FTA were required to identify services sub-sectors in their positive list schedule that would be subject to a standstill, meaning no more restrictive measure could be adopted in the future for those sub-sectors. ${ }^{37}$

\footnotetext{
${ }^{36}$ These may include national treatment, local presence, performance requirements, senior managers, and boards of directors.

${ }^{37}$ Agreement between Japan and the Republic of Indonesia for an Economic Partnership Agreement 2007, Articles 81.3 and 81.4.
} 
- RCEP allows parties to use either a positive or negative list; only Australia has chosen the latter. ${ }^{38}$ However, additional requirements have been proposed for RCEP's positive lists. The parties would have to apply a standstill and ratchet to their limitations for a minimum number of those sub-sectors on which they have made commitments with limitations. They must also either identify sectors in their schedules to which they will apply the most-favoured-nation (MFN) rule to future FTAs ('MFN forward') ${ }^{39}$ or draw up a 'transparency list' that describes the current measures that are protected in their schedules, with the clear intention that these can be converted into a negative list annex in the future.

- In the GATS, commitments on the commercial establishment of services (mode 3) are made in the positive list services schedule. Some agreements that have investment chapters leave mode 3 in the services schedule, while non-services investment is covered in a negative list annex. Drafting and interpreting these schedules become technically complex, especially as the boundary between services and non-services investment is unclear and different classifications systems may be used. ${ }^{40}$ Alternatively, all forms of investment might be covered by the negative list annexes, which makes it difficult to compare a country's mode 3 commitments in its positive list agreements.

(iii) Sectoral chapters or annexes may require full or a minimum level of commitments on particular sectors, sub-sectors, or modes (especially mode 1).

\subsubsection{Domestic regulation}

In addition to standard market access and national treatment rules, there is pressure for new disciplines on how governments can regulate licensing requirements and procedures, ${ }^{41}$ qualification requirements and procedures, ${ }^{42}$ and technical standards. ${ }^{43}$ All three forms of regulation are crucial for digitally provided services. They are already difficult to apply when services are operated across the border.

\footnotetext{
${ }^{38}$ RCEP, Text proposal from Australia, New Zealand, and the Republic of Korea, Article [X], Schedule of Specific Commitments, undated.

${ }^{39}$ Requiring RCEP parties to receive any better treatment provided in future FTAs.

${ }^{40}$ ISIC is often used for investment schedules.

${ }^{41}$ The authorization of a company and/or personnel to supply a service and the procedures to gain a licence.

${ }^{42}$ The competence of a person to supply a service, and which the person needs to show before she or he is authorized to supply that service, and the administrative and procedural rules to show the person complies.

${ }^{43}$ Measures that lay down the characteristics of a service or the manner in which it is supplied.
} 
Developing countries have successfully resisted demands for such disciplines in the GATS. The TPP and TiSA texts are also limited because the US cannot restrict the regulatory authority of its states. However, there is a major push to include sweeping disciplines on these forms of domestic regulation in RCEP and recent EU FTAs, and renewed pressure in the WTO. The proposed restrictions could apply to central, regional, and local governments as well as delegated bodies, such as professional associations.

The following wording is from recent EU FTAs: ${ }^{44}$

- Measures relating to licensing requirements and procedures and qualification requirements and procedures must be based on criteria that are clear, objective, transparent, made public in advance (the EU-Vietnam and EU-Tunisia said established in advance), and accessible.

- Licensing and qualifications procedures must be clear, made public in advance, ensure applications are dealt with objectively and impartially, be as simple as possible, and not themselves restrict the supply of the service or the pursuit of any other economic activity.

- Authorization fees must be reasonable, transparent, and not themselves restrict the supply of the service or pursuit of any other economic activity (this does not include fees for use of natural resources, fees for government procurement tenders, or contributions to universal service obligations).

- Procedures and decisions must be impartial and reached independently. Time frames must be reasonable for applicants but limited for the authorities, who must also explain the reasons for their decisions and provide for appeals.

The bland terminology of 'reasonable', 'objective', 'impartial', and 'transparent' obscures the extent to which current and future regulatory approaches would become open to challenge. They would also impose significant administrative and budgetary burdens on all levels of government, even where application of the obligations is limited by a party's schedule or negative list of reservations.

Technical standards are especially important for the digital economy, as they include the rules on how and where data is stored or used; quality and operating standards and practices for the Internet, telecommunications, and e-finance; conflicts of interest and ethical

${ }^{44}$ For example, CETA Chapter 12. 
codes; universal service obligations; and consumer protections and privacy rules. The new disciplines on technical standards tend to be weaker; for example, the domestic regulation chapter in CETA does not mention them, but they are explicitly covered in the telecommunications chapter, especially for rights of interconnection ${ }^{45}$.

The author understands that New Zealand and Australia are pressing for strong disciplines in RCEP across all these areas of domestic regulation. That includes a requirement for governments to ensure that measures do not constitute 'unnecessary barriers to trade in services', which means choosing the regulatory option that imposes the least burden on commercial interests to achieve permitted objectives.

Finally, measures of general application that affect services transactions must be administered in a reasonable, objective, and impartial manner. These open-ended words invite disputes over the administration of a wide range of services, especially services delivered across the border (mode 1). They could apply, for example, to a decision not to grant a licence or authorization to operate a service, processes for proving the authenticity of an offshore supplier's qualifications, disclosure and reporting requirements, procedures to assess compliance with consumer protection laws, or disciplinary actions and penalties imposed for a regulatory breach. This provision might also apply to tax measures.

\subsubsection{Specialist sectoral annexes}

Financial services and telecommunications have always been a priority for developed countries in trade in services agreements. Most US and EU FTAs either require the parties to adopt the voluntary GATS Reference Paper on Basic Telecommunications or incorporate the provisions of an extended version of the Reference Paper into a chapter or annex on telecommunications. The TPP and TiSA impose special obligations on major public telecommunications providers, which are implicitly targeted at public monopolies in development countries (Kelsey, 2017). Specific obligations on interconnection, access to unbundled services, rights of resale, and limits on universal service obligations all advantage large foreign telecommunication and digital providers.

Digitization has also reordered financial services priorities. E-commerce requires secure and fast payment systems. Traditional banking transactions are cumbersome and costly. Most e-commerce is now conducted through electronic payment systems that use the major international credit cards, Visa and MasterCard, and specialist online exchanges such as

\footnotetext{
${ }^{45}$ CETA Article 15.6
} 
PayPal, Poli, and Alipay. Payment services are often integrated with platforms: eBay bought PayPal in 2002 but spun it off in 2015; Google has created Google Wallet; Apple has ApplePay. Alibaba's banking and finance arm Ant Financial provides a broad range of financial services to more than 450 million customers. It operates the Alipay mobile payment platform at home and markets it to offshore retailers with a large Chinese customer base (Bradley, 2017). Alipay and other payments platforms are integral to Jack Ma's ecommerce 'ecosystem.'

Digitally enabled cross-border financial services are highly lucrative in their own right and present serious regulatory challenges as the finance industry finds ever-more creative and non-transparent ways to circumvent national regulation. Product and qualification standards, ethical codes, and the company's employment practices can become impossible to monitor effectively or enforce when, for example, insurance companies operate from offshore through call centres or online. Financial and tax regulation may be rendered impotent if offshore financial firms are not required to have any local presence or store data locally.

Many ASEAN countries have already taken commitments on financial services in mode 2 , and sometimes mode 1 as well. That is problematic, given uncertainty about how modes 1 and 2 are interrelated: for instance, cross-border financial transactions are mode 1, but the offshore bank account involved in those transactions is probably consumption of a service abroad (mode 2).

The mega-agreements may require countries to allow the sale of any 'new financial services or products' that are not currently provided in their territory, but are available in the territory of the other party. The precedent was established in the voluntary Understanding on Commitments in Financial Services among some WTO members. ${ }^{46}$ The preconditions vary. Some agreements say the provider of the new service or product must be established in the receiving country, ${ }^{47}$ that presumably increases the financial regulators' ability to apply prudential measures, although the standard exception is weak and circular (Lang and Amarasekara, 2017: 30). Other agreements require the financial service or product to be permitted under the country's existing law; ${ }^{48}$ yet innovative financial products are usually designed to circumvent existing regulations. These pre-commitments not to regulate as yet

\footnotetext{
${ }^{46}$ Understanding on Commitments in Financial Services, Articles A and B.3-6.

${ }^{47}$ For example, Japan-EU FTA, Article 3.

${ }^{48}$ For example, TPP, Article 11.7.
} 
unknown services and products pose especially high risks in an era when electronic trading in toxic financial products has contributed to contagious financial crises.

\subsubsection{Transparency}

'Transparency' provisions in the GATS require governments to make their laws, regulations, criteria, and procedures publicly available, and provide applicants with information on the progress and outcomes of licensing applications and authorizations. The mega-agreements extend this by providing rights for governments and their corporations to be informed of proposed new regulations in advance. Many developed countries already provide such opportunities in the name of 'best practice regulation'. An EU-led proposal on transparency in domestic regulation (WTO, 2017e) and India's Trade Facilitation for Services proposal (WTO, 2017f) are promoting the same obligations in the WTO.

The transparency obligation may be couched as a 'best endeavour'. ${ }^{49}$ The wording is usually neutral, referring to 'interested persons'. In reality, major commercial interests and industry groups have superior resources to generate reports and submissions, and lobby governments (Azmeh and Foster, 2016:12-14, Table 1 and Figure 1). This entitlement can therefore skew the balance of interests in the lawmaking process, and increase the potential chilling effect if foreign corporations threaten to withdraw their investment or bring an investment dispute if the proposals proceed. There are already examples of tech corporations making such threats over new taxes and stricter regulation (Anderson, 2017).

\section{$5 \quad$ E-Commerce Rules}

The electronic commerce chapters or annexes in the mega-agreements embody virtually all the US tech industry's demands. As noted earlier, the label e-commerce is misleading; very few of the rules are about commercial transactions per se. They embed the power of incumbents and erect barriers to digital industrialization by developing countries and their affordable and reliable access to GVCs. The TPP, TiSA, RCEP, EU-Japan FTA, and WTO proposals share three substantive elements, although individual agreements vary: ${ }^{50}$

\footnotetext{
${ }^{49}$ For example, TPP, Article 26.2.

${ }^{50}$ For example, some rules in Chapter 9: E-Commerce of the Agreement between Japan and Mongolia for an Economic Partnership go beyond the TPP: an indefinite extension of the temporary moratorium on customs duties on electronic transmissions (Article 9.3) and a necessity test is imposed on Domestic
} 
i. Prohibitions on national requirements to store or process data locally, transfer or provide access to source code, use local computer facilities, include local content in electronic transmissions, and transfer technology as a condition of foreign investment;

ii. Weak provisions on the protection of consumers and personal information, restrictions on censorship, unsolicited commercial electronic messages (spam), and access to and use of the Internet and open networks; and

iii. Promoting actual cross-border commerce by eliminating customs duties on electronic transmissions, streamlining transactions through electronic authentication and esignatures, and international cooperation.

\subsection{Unrestricted movement of data}

A government cannot stop a service supplier from another party operating in its country from transferring or processing data offshore, including personal or commercial information. While the rules do not explicitly refer to 'storage' of data offshore, such a restriction would be covered as a 'measure that affects trade by electronic means'. ${ }^{51}$ Governments are not allowed even to specify a list of acceptable countries to which the data can be transferred and processed.

Under TiSA, the operator would simply have to establish a need to transfer the data offshore 'in connection with' the conduct of its business. ${ }^{52}$ In other agreements, it is 'for the conduct of the business, ${ }^{53}$ which would protect the export of data by operators of search engines and digital market places, as well as sectors like insurance, tourism, online education, and mining. Some agreements exclude government data from the rule; others may not. ${ }^{54}$ In practical terms, an Australian private hospital operator in Thailand could not be prevented from transferring Thai patients' health data outside the country. The Indonesian government could not require a US-owned mining operator to hold data, such as safety records or inventory, within Indonesia. Uber could not be required to store financial records of local transactions in Malaysia for tax purposes.

Regulation (Article 9.9); but there is no formal prohibition on data localization requirements. In the ecommerce chapter of the EU-Japan FTA, both Japan and the EU agreed to TPP-plus rules, but deferred the question of data transfers which the EU has yet to resolve internally.

${ }^{51}$ For example, TPP, Article 14.2.2.

52 Proposal in TiSA, Article 2.2, Annex on Electronic Commerce, undated (November 2016).

${ }^{53} \mathrm{TPP}$, Article 14.11.

${ }^{54}$ This has not been decided, for example, in TiSA. 
When personal and commercial information is held offshore, including 'in the cloud', it is beyond the subject's control. The company that holds the data will choose the repository, but even it may not know which country the server is located and whose privacy and consumer regimes apply. Once the data is offshore, the government may lose the ability to regulate its use, abuse, or sale unless it can impose effective licensing or technical standards within whatever domestic regulation disciplines apply in the agreement.

A government might be allowed to keep or adopt a measure that restricts the movement of information to achieve a 'legitimate public policy objective'. What qualifies as a legitimate objective would ultimately be decided by a panel of trade experts. If its scope was limited to objectives that are widely recognised internationally, it would be difficult for governments to be proactive or take precautionary approaches to emerging problems. A measure that was considered legitimate might still be disallowed if it was applied in a way that constitutes 'arbitrary or unjustified discrimination' (even though the measures might be especially pertinent to foreign suppliers) or was a disguised restriction on 'trade', broadly defined. ${ }^{55}$ The latter would rule out digital industrialization measures.

Rules that prohibit so-called 'data localization' need to be read alongside a country's commitments on cross-border services. A government could already be prohibited from requiring data localization through commitments in a positive list schedule for data processing or database services, or a negative list that has no relevant reservations. A requirement to hold data in the country might also be problematic as a 'measure affecting the supply' of a committed sector if it was a condition of licensing or a technical standard for supplying the service, or an aspect of administering regulations of general application. The uncertainty and constantly expanding scope of these rules deepen the uncertainty that confronts local policymakers.

There are special sensitivities about the transfer and location of financial data, especially at times of financial crisis or insolvency of individual firms. The finance industry argues that:

Data location regulations reduce efficiency by requiring institutions to retain people and technology in local markets that they otherwise would not require, reducing margins and resources available for reinvestment. The rules degrade a financial institution's ability to

\footnotetext{
${ }^{55}$ Proposed in TiSA, Article 2.3, Annex on Electronic Commerce, undated (November 2016). The US has not agreed to this.
} 
provide service in a seamless way to customers across countries and regions. (Kaplan and Rowshankish, 2015: 2)

The US Treasury blocked the inclusion of financial data in the movement of information provision in the TPP. Under pressure from the industry, the USTR later proposed its inclusion in TiSA (Kelsey, 2017). The EU-Vietnam agreement required the parties to allow the financial service provider to transfer information in electronic form or other form into or out of the country for data processing in the ordinary course of business from 2 years after its entry into force. Each party is required to adopt or maintain 'appropriate safeguards' to protect privacy and personal data, including personal records and accounts. ${ }^{56}$ The language proposed by Japan in the EU-Japan FTA for unrestricted movement of financial data has not been agreed. ${ }^{57}$

\subsection{Location of computer facilities}

A government cannot require the use or location of computing facilities inside the country as a condition of supplying a service in that country. ${ }^{58}$ 'Computing facilities' means 'computer servers and storage devices for the processing or storing information for commercial use'. ${ }^{59}$ This ban is a major disincentive for governments to invest in upgrading their local infrastructure for domestic use in the hope of attracting foreign firms. Lack of such investment reinforces the country's long-term dependency on foreign-owned and located infrastructure. A similar provision on legitimate public policy objectives to that on data transfers may apply. However, the TPP imposed an additional constraint that restrictions relating to local computer facilities must be no greater than needed to achieve the public policy objective (a necessity test). ${ }^{60}$

\subsection{Prohibited performance requirements}

The WTO's Agreement on Trade-Related Investment Measures (TRIMS) prohibits the imposition of certain goods-related performance requirements on foreign investors. Megaagreements have expanded TRIMS to services. These provisions may be located in the investment, services or e-commerce chapters. ${ }^{61}$ The list of prohibitions has expanded in

\footnotetext{
${ }^{56}$ EU-Vietnam FTA, Article (...) [sic]: Data processing.

${ }^{57}$ EU-Vietnam FTA, Article (...) [sic], Transfers of Information and Processing of Information.

${ }^{58}$ For example, TPP, Article 14.13.

${ }^{59}$ For example, TPP, Article 14.1.

${ }^{60} \mathrm{TPP}$, Article 14.11.3(b).

${ }^{61}$ For example, in TPP, Article 9.10 Performance Requirements is in the investment chapter.
} 
recent agreements and may ban requirements to (i) use local content (even in return for a subsidy), (ii) transfer technology and proprietary knowledge, (iii) use local or a particular technology, (iv) employ and train local personnel if that involves transfer of proprietary knowledge, and (v) consider trade balance. These are all common elements of a digital industrialization strategy. Governments are usually allowed to schedule reservations to these rules, subject to the difficulties noted earlier.

\subsection{No local content requirements on e-supply}

The US promotes a further rule that content supplied electronically must not receive more favourable treatment because it was created, produced, published, contracted for, commissioned, or first made available on commercial terms locally, or where the creator, producer, developer, or owner is local. ${ }^{62}$ That rule would prevent central or local governments from using preferences to support local firms to develop content or requiring use of local knowledge and cultural content to enhance the quality of the service provided. This restriction is most obviously targeted at the entertainment industry, apps and games. But it applies equally to services like education, consultancy, and research and development. It would not apply to subsidies or grants, government-supported loans, guarantees, and insurance. ${ }^{63}$

\subsection{Keeping source codes secret}

A source code is the formula for a computer programme that humans can read, which is then converted into an object code or machine code that the computer can be read. It can encompass anything from software in smart products to the algorithms used to run Google's search engines and Amazon's digital marketplace. Open source means it is accessible to everyone to use, copy, check, alter, or correct. Protected source codes could be described as trade secrets, which most countries protect under their competition or contract law.

5.5.1 The non-disclosure rule: The basic rule on source codes says a government cannot require a person (firm or individual) of another party who owns software to transfer or provide access to the source code for that software as a condition for being allowed to supply the service. ${ }^{64}$ The EU-Japan FTA goes further; it bans disclosure requirements that would

\footnotetext{
${ }^{62}$ TiSA, Article 10.3, Annex on Electronic Commerce, undated (November 2016), proposed by the US.

${ }^{63}$ TiSA, Article 10.5, Annex on Electronic Commerce, undated (November 2016).

${ }^{64} \mathrm{TPP}$, Article 14.7.
} 
affect 'trade by electronic means'. ${ }^{65}$ The ban includes transfer of source codes to a government. There is no ability to schedule a reservation on the source code provision. A 'legitimate public policy' defence might apply, similar to the prohibition on restricting movements of data. But the measure must be accepted as 'legitimate', not involve 'arbitrary' or 'unjustified discrimination' against the owner of source code, and not be a disguised restriction on trade - again, excluding its use for digital industry policy. If it failed that test the government would have to rely on the general or security exception (discussed below).

As with the rule on data transfers, a requirement for disclosure of source code could also be a licensing condition or a technical standard for the delivery of certain services. That could bring it under the 'disciplines' on domestic regulation proposed for the WTO and RCEP.

\subsubsection{Economic implications}

Monopoly rights over source codes have significant economic implications. Source codes are essential to competition and developing countries' participation in the smart economy. Without such access, they are competing on an un-level playing field. There are parallels to the previous era of industrialization where intellectual property rights were used to shut the door on developing countries' ability to catch up. At least with patents, the disclosure requirement makes it possible for competitors to enter the market once the patent expires, as generic medicine producers do. The source code monopoly has no such disclosure requirement.

Relying on expensive imported technology makes domestic production uncompetitive. China has faced barriers to its goal of becoming a major producer of artificial intelligence for domestic and offshore use because the three main components of its robots are all imported and comprised $70 \%$ of production costs (Ma, 2017). This barrier can only be overcome by reverse engineering, which is extremely difficult with source codes; development of new knowledge, which few ASEAN countries would have the capacity to do; or compulsory disclosure of source codes. In addition, the secondary industry of component manufacturers and servicers of smart products would be unable to supply the necessary information.

${ }^{65}$ EU-Japan FTA, Articles 4 and 1.4. 
5.5.3 Non-economic implications: Secrecy of source codes also poses non-economic risks. ${ }^{66}$

- Corporate non-compliance: Computer programmes are now embedded in smart products, from household appliances to motor vehicles to running shoes. Nondisclosure of source codes makes it impossible to monitor compliance with product standards. Volkswagen's fraudulent software for monitoring emissions, which was discovered fortuitously by researchers (Hotten, 2015), shows the importance of disclosure for consumer protection, enforcing environmental standards, and prosecuting criminal acts.

- Judicial proceedings: Disclosure is a crucial evidential tool in civil proceedings, such as determining responsibility for faulty software or identifying algorithms used to manipulate financial trades or engage in anti-competitive practices, as in the case of Google. While the EU-Japan FTA allows governments to require disclosure of source codes to remedy a violation of competition laws, it does not cover disclosure to prove a violation.

- Security and safety: As well as errors and design faults in software, there are growing risks from hacking and installing of malware. Those risks will intensify with the rapid expansion of $\mathrm{AI}$ and use of drones, robots, and driverless vehicles. Attacks on individuals or premises may also be routed indirectly through less secure software.

- Financial risk and fraud: Complex algorithms are used to engineer financial products; conduct automated trading in currency, shares, and derivatives; allocate ratings to financial products; and assess risk for insurance. If the e-commerce annex applies to financial services, the secrecy of source code will fetter financial regulators and enable destabilizing and/or unlawful financial practices associated with fraud, company collapses, and financial crises. ${ }^{67}$

- Manipulation of information: Algorithms may be used for practices that conflict with laws on consumer, labour, or human rights. Without access to them, it may be impossible to verify, let alone successfully prosecute, a breach. Examples include:

o profiling that can lead to anti-consumer practices, such as arbitrary bans on access to digital marketplaces or activities (such as no-fly lists);

\footnotetext{
${ }^{66}$ Based on research by Sanya Reid Smith, Third World Network, Malaysia, 2017.

${ }^{67}$ For example, the London Interbank Offer Rate (LIBOR) that provides the benchmark for interest rates from the City of London was subject to fraudulent manipulation by bankers in 2012-2014 (Vaughan and Finch, 2017).
} 
o differential charges for services based on search history (so-called dynamic pricing);

O search algorithms that prioritize sites that promote propaganda, racist, Islamaphobic, or other extreme views (Abdelaziz, 2017);

o employment decisions, performance monitoring, and evaluation and rating of applicants and employees, who have no ability to challenge the criteria or assessments;

○ risk assessments for credit ratings or health insurance, based on assumptions about gender, race, income, and other factors; and

o social and political manipulation by selective displays of information and advertising (for example, Google showing ads for prestigious jobs only to men (Carpenter, 2015).

\subsection{Legal protections}

There are various possible protections from the e-commerce rules, but they are very restricted.

\subsubsection{Schedules}

Parties cannot schedule limitations on the most significant obligations, which deal with movement of information, location of computing facilities, source codes and local content (except as a performance requirement).

\subsubsection{Consumer protection}

Consumers are likely to presume that their domestic laws, dispute mechanisms, and remedies apply to e-commerce transactions. Where the service is provided from offshore, they may become reliant on a foreign jurisdiction without knowing it. Some agreements do not impose any consumer protection obligations on the parties. For example, the EU Japan FTA merely recognises the importance of consumer protection measures. ${ }^{68}$ The TPP requires countries to adopt consumer protection laws but does not set any level, and restricts their scope to laws that 'proscribe fraudulent and deceptive commercial practices that cause harm or potential harm to consumers engaged in online commercial activities'. ${ }^{69}$ Other anti-

\footnotetext{
${ }^{68}$ EU-Japan FTA, Article 9, Chapter VI: Electronic commerce.

${ }^{69}$ TPP, Article 14.7
} 
consumer practices, such as re-routing, geo-blocking, and price discrimination are not mentioned.

These flexibilities might reduce the compliance burden on ASEAN countries that do not yet have robust consumer protection regimes. ${ }^{70}$ But they presumably will want to improve those protections in the future. The trade in services disciplines on licensing requirements and procedures, technical standards, and administration of general regulations could restrict the quality of measures they can adopt. The transparency rules would also guarantee foreign states and foreign firms the right to lobby against effective new consumer protection laws.

\subsubsection{Privacy protection}

The TPP adopts a similar approach to 'protection of personal information' as it does to consumers, although it suggests parties 'should take into account' principles and guidelines of international bodies. This hands-off approach protects the US's weak privacy regime. The US proposal in TiSA would allow private firms to decide how to reconcile the different privacy regimes that apply to a cross-border transaction. ${ }^{71}$ The EU is still holding internal discussions to find an acceptable balance between offshore data flows and the constitutional protection of privacy in its FTAs (Fortnam, 2017).

\subsubsection{The general exception}

The general exception offers a defence when a measure has otherwise breached a party's obligations. The GATS exception is imported into most mega-agreements in relation to ecommerce. ${ }^{72}$ However, the inclusion in the e-commerce chapters of some of these agreements of additional provisions on protection of personal information and of consumers, which use similar but different wording and which apply to only some e-commerce provisions, creates uncertainty. ${ }^{73}$ It could imply that the general exception does not apply to those provisions or is considered too narrow or too weak.

\footnotetext{
${ }^{70}$ This gap is common across developing countries. Despite India's promotion of free data flows in the WTO, as part of its Trade Facilitation in Services proposal, the Government of India announced only in April 2017 that it would develop a regulatory regime for data protection (PTI, 2017).

${ }^{71}$ TiSA, Article 4.3, Annex on Electronic Commerce, undated (November 2016).

${ }^{72}$ For example, GATS Article XIV is imported into TPP, Article 29.1.3.

${ }^{73}$ EU-Japan FTA, Article VI.4 Source Code.
} 
The general exception in relation to consumer protection and privacy is certainly more restrictive than for health, environment, public order, and public morals. First, the measure must relate to one of two narrow matters:

- fraud or default on services contracts (no other forms of consumer protection); or

- $\quad$ processing and dissemination of an individual's data and confidentiality (but not, for example, for use or storage of data).

Next, the measure must be adopted to secure compliance with a law or regulation that is consistent with the agreement. A government might, for example, impose a local data processing requirement as part of implementing its privacy law. That measure would breach the data localization rule in the e-commerce chapter. The government could only rely on the exception if the privacy law itself was consistent with the agreement. The exception would not be available, for example, if the privacy law itself required data to be held in the country, required disclosure of source code, or was discriminatory in its treatment of foreign operators and therefore breached the government's national treatment obligation.

Third, the measure must be necessary to implement that law, meaning, there was no less burdensome approach reasonably available to do so.

Finally, a measure that falls within the two narrow categories of consumer and privacy protections, implements a law that complies with the agreement, is the least burdensome approach reasonably available to do so, must also not involve arbitrary or unjustifiable discrimination between the countries where 'like' conditions prevail or be a disguised trade restriction that favours domestic suppliers or services.

\subsubsection{Censorship}

States are legitimately concerned to protect their regulatory sovereignty from binding and enforceable guarantees to foreign corporations. Yet corporations are not the only threats to citizens' rights in the rapidly expanding digital domain. Powerful states have the technology and leverage to manipulate and censor information in ways that violate free speech and citizens' rights in their own and other countries. All states have some capacity to do so by censoring free access to platforms and information, through law or practice, in violation of the right to freedom of opinion and expression under Article 19 of the Universal Declaration of Human Rights. 
The mega-agreements make no genuine attempts to protect the interests of digital users as consumers, let along as citizens who have fundamental human rights. The general exception includes a category of measures to protect public order or morals, which is subject to a necessity test and the standard chapeau. China was allowed to invoked the public morals justification as a defence in the WTO dispute brought by the US over restrictions on the importation and distribution of goods and services with 'cultural content', but it failed to satisfy the necessity test because there were less restrictive alternatives (Pauwelyn, 2010). However, aggrieved citizens cannot bring a dispute challenging a measure for violation of their rights. They require another state party to do so, and its decisions will be driven by its own commercial and strategic interests. This dilemma highlights the inappropriateness of a trade agreement as the vehicle through which to devise an Internet governance regime that requires a balancing of diverse international and domestic obligations.

\subsubsection{Security exception}

The standard security exception applies across the mega-agreements. A state can judge for itself whether a measure is 'necessary' in its 'essential security interests'. However, the defence is available only in limited circumstances. The most relevant situation is an 'emergency in international relations'. That seems to exclude longer-term measures that are precautionary or general, such as for cybersecurity.

In TiSA, the US and several other countries proposed a specific security exception for the e-commerce annex that gives governments stronger rights: a government could define what are its 'essential security interests' and what action it considers is necessary to protect them. ${ }^{74}$ Japan asked for more clarity on what 'essential security interests' means. This approach would allow governments to exploit the elastic, self-defined concept of 'security' in an era of 'terrorism' and 'cyber threats' to their own purposes. It makes much more sense for governments not to adopt obligations for which they might require such an exception.

\section{The Challenge for ASEAN}

This paper shows that developing countries, including ASEAN, are rule-takers not rulemakers in the new generation mega-agreements. The normative regime that is systematically

${ }^{74}$ TiSA, Article 13, Annex on Electronic Commerce, undated (November 2016). 
being developed aims to guarantee the continued monopoly of already dominant, mainly US, companies over source codes, data and digital technologies, and facilities. Parminder Singh warns of 'a significant mismatch between the most important geo-economic and geopolitical implications of the digital phenomenon and the way developing countries have been viewing it at the global level. This has resulted in developing countries getting trapped in new extractive global economic relationships, and also excluded from processes shaping the global digital norms and policies' (Singh, 2017:6). Of the large, well-resourced developing countries only China seems equipped to compete, and that prospect carries its own risks of dependency for ASEAN.

It is crucial that ASEAN members have the time and flexibility to identify and develop appropriate national and regional regulatory frameworks that can advance their digital industrialization, individually and in solidarity. These frameworks might include rules on:

- binding technology transfer and mandating disclosure of source code to encourage the development of infrastructure and domestic suppliers;

- requiring data localization, joint ventures, and use of local facilities for the development of domestic capacities;

- training of a skilled IT workforce; and

- commitments to financial assistance for technology development and infrastructure in order to bridge the digital divide and facilitate e-commerce.

The new normative regime that is being promoted by developed countries in the megaagreements, especially the TPP, RCEP, the WTO, and EU FTAs, would foreclose those options in ways that are practically impossible to undo. ASEAN members will need to resist those proposals if they are to maintain their regulatory sovereignty and the policy space to capitalize on the 21 st century digital revolution.

\section{References}

Abdelaziz, R.(2017), 'Google Search Is Doing Irreparable Harm to Muslims', Huffington Post, 29 June 2017, Available at: http://www.huffingtonpost.com/entry/googlesearch-harming-muslims_us_59415359e4b0d31854867de8

Adlung, R. and R. Martin (2005), 'Turning hills into mountains? Current commitments under the GATS and prospects for change', WTO Staff Working Paper ERSD 2005-01, March 2005. 
Al Jazeera (2017), 'The great firewall update: Clamping down on VPNs', Al Jazeera, 12 August 2017, Available at:

http://www.aljazeera.com/programmes/listeningpost/2017/08/great-firewallupdate-clamping-vpns-170812090721781.html

Alibaba (2017), 'Alibaba turns eWTP into reality with the Creation of the First Overseas E-hub', 22 March 2017, Available at:

http://www.alibabagroup.com/en/news/article?news=p170322

Anderson, F. (2017), 'Esty, Amazon, Alibaba join eBay in threat to block Australian consumers in GST war', Australian Financial Review, 21 April 2017, Available at: http://www.afr.com/news/politics/etsy-ebay-and-alibaba-join-amazon-in-threat-toblock-australian-consumers-in-gst-war-20170420-gvp951

Author Earnings (2016), ‘February 2016 Author Earnings Report: Amazon's Ebook, Print and Audio Sales', Available at: http://authorearnings.com/report/february-2016author-earnings-report/

Azarhoushang, B., A. Bramucci, H. Herr, B. Ruoff (2015), 'Value chains, underdevelopment and union strategy', International Journal of Labour Research, 7(1-2), pp.153-175.

Azmeh, S.and C. Foster (2016), 'The TPP and the Digital Trade Agenda: Digital Industry policy and Silicon Valley's influence on new trade agreements', January 2016, London: London School of Economics.

Banga, Rashmi (2017), 'Rising Product Digitalisation and Losing Trade Competitiveness', CWS Working Paper no. 39, June 2017, New Delhi: Centre for WTO Studies.

BBC (2017), 'Massive ransomware infection hits 99 countries', BBC, 13 May 2017, Available at: http://www.bbc.com/news/technology-39901382

Behsudi, A. (2017), 'Amazon Snatches up Punke’, Politico, 21 February 2017, Available at: http://www.politico.com/tipsheets/morning-trade/2017/02/china-among-pacificnations-confirmed-for-chile-meeting-218838

Buck, T. and P.Hollinger (2017), 'British Airways faces $£ 80 \mathrm{~m}$ cost for IT failure that stranded 75,000', Financial Times, 15 June 2017, Available at: https://www.ft.com/content/98367932-51c8-11e7-a1f2-db19572361bb

Bradley, G.(2017), 'Auckland Airport's Alipay milestone', NZ Herald, 17 April 2017, Available at:

http://www.nzherald.co.nz/business/news/article.cfm?c_id=3\&objectid=11837242

Carpenter, J. (2015), 'Google's algorithm shows prestigious job ads to men, but not to women', Independent, 7 July 2015, Available at:

http://www.independent.co.uk/life-style/gadgets-and-tech/news/googles-algorithmshows-prestigious-job-ads-to-men-but-not-to-women-10372166.html

Caporal, J. (2017), 'Wyden, internet giants lay out digital trade priorities for NAFTA redo’, Inside US Trade, 30 June 2017.

Choudhary, M. and E.Moglen (2017), 'Head off digital colonialism: How Indian IT can compete with Google and Facebook and show the world a better way', India Times, 29 May 2017, Available at: http://blogs.timesofindia.indiatimes.com/toiedit-page/head-off-digital-colonialism-how-indian-it-can-compete-with-googleand-facebook-and-show-the-world-a-better-way/ 
Cory, N.1 (2017), 'The Worst Innovation Mercantilist Policies of 2016', January 2017, Information Technology and Innovation Foundation, Washington D.C.

Council of the European Union (2017) 'Concept paper on data flows in trade agreements', 27 January 2017, WK 959/2017 INIT.

Crowell Moring (2017), 'Robert Holleyman', Available at: https://www.crowell.com/Professionals/Robert-Holleyman

Deutsche Welle (2016), 'The world's biggest Internet based companies', 4 August 2016 Available at: http://www.dw.com/en/the-worlds-biggest-internet-basedcompanies/g-19446253

Dragoo, H. (2017), 'China's Cybersecurity Law: The Impact on Digital Trade', 7 August 2017, Available at: http://www.internetgovernance.org/2017/08/07/chinascybersecurity-law-the-impact-on-digital-trade/

European Commission (EC) (2017), 'Antitrust: Commission fines Google $€ 2.42$ billion for abusing dominance as search engine by giving illegal advantage to own comparison shopping service', 27 June 2017, Available at: http://europa.eu/rapid/press-release_IP-17-1784_en.htm

European Commission (2017a), Report of the second round of negotiations for a Free Trade Agreement between the European Union and Indonesia, 24-27 January 2017, trade.ec.europa.eu/doclib/html/155297.htms

European Union (EU) (2017), Communication on Exchanging and Protecting Personal Data in a Globalised World, COM (2017).

EUSME Centre (2016), 'China to Establish New Cross-border E-commerce Pilot Zones in 12 Cities', EUSME Centre, 10 January 2016.

Fioretti, J.(2017), 'EU to launch more e-commerce antitrust investigations', Reuters Technology News, 10 May 2017, Available at: http://www.reuters.com/article/eucompetition-geoblocking-idUSL1N1IC22B

Fortnam, B. (2017), 'EU decision on data flow language in TiSA not expected until fall; U.S. position still unknown', Inside US Trade, 13 February 2017.

Fung, B. (2017), 'Amazon's Huge Cloud Computing Outage Tracked to Bad Keystrokes', Washington Post, 2 March 2017, Available at: http://www.nzherald.co.nz/business/news/article.cfm?c_id=3\&objectid=11811188

G7 (2016), 'Principles and Actions on Cyber', 27 May 2016.

G20 (2016), Digital Economy Development and Cooperation Initiative, Hangzhou, China, 5 September 2016.

GATT (1991), Services Sectoral Classification List, MTN/GNS/W/120, 10 July 1991.

Global Innovation Forum (GIF) (2017), 'In Geneva, NFTC's Global Innovation Forum Discusses Impact of Global E-Commerce on Small Businesses and Development', 28 April 2017, Available at: http://www.globalinnovationforum.com/in-genevanftcs-global-innovation-forum-discusses-impact-of-global-e-commerce-on-smallbusinesses-and-development/

Gonzalez, A. (2016), 'The Day a Cyber Attack Brings the World's Supply Chains to a Halt', Leadership \& Management, Logistics \& Supply Chain, 8 September 2016. 
Greiger, G. (2016), 'One Belt, One Road (OBOR): China's Regional Integration Initiative', Briefing to the European Parliament, 7 July 2016.

Hotten, R. (2015), 'Volkswagen: the scandal explained', BBC, 10 December 2015, Available at: http://www.bbc.com/news/business-34324772

Hu, Jia-Xiang (2013), 'When Trade Encounters Technology: The role of the technological neutrality principle in the development of WTO rules' in Bryan Mercurio and Kuei-Jung Ni (eds.), Science and Technology in International Economic Law: Balancing Competing Interests, Routledge, 2013, 75-89.

Information Technology Industry Council (ITIC) (2016), 'USTR Request for Public Comments to Compile the National Trade Estimate Report (NTE) on Foreign Trade Barriers', 27 October 2016.

Inside US Trade (2017), 'EU decision on data flow language in TiSA not expected until fall; U.S. position still unknown', Inside US Trade, 13 February 2017.

International Digital Economy Alliance (IDEA) (2013), 'The Trillion Dollar Question. How trade agreements can maximise the economic potential of data in the networked economy and support the Internet as the world's trading platform', Geneva: IDEA.

Internet Association to Hon Robert Lighthizer, 16 May 2017, Available at: https://cdn1.internetassociation.org/wp-content/uploads/2017/05/Lighthizer-Letter5.16.pdf

Kaplan, J.and K. Rowshankish (2015), 'Addressing the Impact of Data Location Regulation in Financial Services', Global Commission on Internet Governance Paper Series No. 14, May 2015.

Kelsey, J. (2017), TiSA - Foul Play, UNI Global Union, pp.132-133.

Khan, A. W. (2009), 'Universal Access to Knowledge as a Global Public Good', Global Policy Forum, June 2009, Available at: https://www.globalpolicy.org/social-andeconomic-policy/global-public-goods-1-101/50437-universal-access-toknowledge-as-a-global-public-good.html

Khor, M. (1996), 'Will WTO Competition End Oligopolies?', SunsOnLine, 18 December 1996. Available at: http://www.sunsonline.org/trade/process/followup/1996/12180096.htm

Knowledge Commons (n.d.), 'Digital colonialism and the Internet as a tool of cultural hegemony', Available at: http://www.knowledgecommons.in/brasil/en/whatswrong-with-current-internet-governance/digital-colonialism-the-internet-as-a-toolof-cultural-hegemony/

Lang, A. and L. Amarasekara (2016), 'Financial Services Liberalisation and TiSA: implications for EU Free Trade Agreements, Report to the European Parliament', July 2016.

Lee, Kai-Fu (2017), 'The Real Threat of Artificial Intelligence', New York Times, 24 June 2017, Available at: https://www.nytimes.com/2017/06/24/opinion/sunday/artificialintelligence-economic-inequality.html

Levy, N. (2017), 'Amazon patents shipping label with built-in parachute for dropping packages from drones', Geekwire, 30 May 2017, Available at: 
https://www.geekwire.com/2017/amazon-patents-shipping-label-built-parachutedropping-packages-drones/

Ma, J. (2016), Letter to Shareholders from Executive Chairman Jack Ma, 13 October 2016, Available at: http://www.alizila.com/letter-to-shareholders-from-executivechairman-jack-ma/

Ma, S. (2017), 'More China-made robot parts is goal', China Daily, 23 May 2017, Available at: http://www.chinadaily.com.cn/china/2017$\underline{\text { 05/23/content_29454196.htm }}$

Mattoo, A. and L. Schucknecht (2000), Trade Policies for Electronic Commerce, Policy Research Working Paper 2380, World Bank, Washington DC.

Microsoft Corporation v Commission (2007) T-201/04, Judgment of the Court of First Instance (Grand Chamber) of 17 September 2007.

Monaghan, Angela (2017), 'Massive cyber-attack could cost Nurofen and Durex Maker $£ 100 \mathrm{~m}$ ', The Guardian, 6 July 2017, Available at:

https://www.theguardian.com/business/2017/jul/06/cyber-attack-nurofen-durexreckitt-benckiser-petya-ransomware

New York Times (2017), 'Russian Hacking and Influence in the U.S. Election', Available at: https://www.nytimes.com/news-event/russian-election-hacking

OECD (2014), Principles for Internet Policy Making, Paris: OECD.

OECD (2016), 'Economic and Social Benefits of Internet Openness', OECD, Paris, Available at: http://www.oecdilibrary.org/science-and-technology/economic-and-socialbenefits-of-internetopenness_5jlwqf2r97g5-en;jsessionid=25r63um1elsw1.x-oecd$\underline{\text { live- } 02}$

Our World Is Not For Sale (2014), 'Leaked TiSA text exposes US threat to privacy, data security and net neutrality', 17 December 2014, Available at: http://notforsale.mayfirst.org/es/node/24452

Patnaik, P.(2015), 'Away From the Glare, a Push for More Stringent IPR Protection at the WTO', The Wire, 2 November 2015, Available at: https://thewire.in/14593/awayfrom-the-glare-a-push-for-more-stringent-ipr-protection-at-the-wto/

Pauwelyn, J. (2010), 'Squaring Free Trade in Culture with Chinese Censorship: The WTO Appellate Body Report on China - Audiovisuals', Melbourne Journal of International Law 119 (2010) 11:1.

Peermohamed, A.(2016), 'India e-commerce industry losses may swell Amazon's \$1 billion loss this year', Business Standard, 23 November 2016, Available at: http://www.business-standard.com/article/companies/indian-e-commerce-industrys-losses-may-swell-on-amazon-s-1-billion-loss-this-year-116112200265_1.html

PTI (2017), 'Will have regulatory regime on data protection: Government to Supreme Court', The Economic Times, 27 April 2017.

PWC (2017), 'Global Top 100 Companies by Market Capitalization', 31 March 2017 update.

Rahman, S. (2016), 'Challenging the new Curse of Bigness', The American Prospect, 29 November 2016, Available at: http://prospect.org/article/challenging-new-cursebigness 
RCEP (2015), Terms of Reference: Working Group on Electronic Commerce. February 2015, Available at:

http://www.bilaterals.org/IMG/pdf/ecommerce_draft_terms_of_reference.pdf

Reuters (2017), 'Hackers hit Russian Bank Customers, Planned International Cyber

Raids', Fortune, 22 May 2017, Available at:

http://fortune.com/2017/05/22/hackers-russian-bank-customers/

Sen, S. (2017), 'Flipkart raises \$1.4bn from Tencent, eBay, Microsoft', Hindustan Times, 10 April 2017, Available at: http://www.hindustantimes.com/businessnews/flipkart-raises-1-4-bn-from-tencent-others-buys-ebay-to-take-onamazon/story-hw59D13ixaxzG08dJFdxSN.html

Shepardson, D.(2017), 'New FCC chair vows "light-touch" approach to regulation', Reuters, 28 February 2017, Available at: http://www.reuters.com/article/us-usafcc-idUSKBN16720Z

Shuiyu, J., Q. Xin, and H. Wei (2017), 'Ali Baba bringing Belt, Road benefits to SMEs', China Daily, 24 April 2017, Available at: http://www.chinadaily.com.cn/business/2017-04/24/content_29051117.htm

Singh, P. J.(2017), 'Developing Countries in the Emerging Global Digital Order - a Critical Geopolitical Challenge to which the Global South Must Respond', Background paper to South Centre presentation, January 2017.

South Centre (2017), 'The WTO's Discussions on Electronic Commerce', SC/AN/TDP/2017/2, January 2017.

South Centre (2017a), 'Micro, Small and Medium-Sized Enterprises', SC/AN/TDP/2017/4, July 2017.

Stoller, K. (2017), 'The World's Largest Tech Companies 2017: Apple And Samsung Lead, Facebook Rises', 24 May 2017, Available at: https://www.forbes.com/sites/kristinstoller/2017/05/24/the-worlds-largest-techcompanies-2017-apple-and-samsung-lead-facebook-rises/\#4f58eacdd140

Taplin, J. (2017), 'Is it time to break up Google?', New York Times, 22 April 2017, Available at: https://www.nytimes.com/2017/04/22/opinion/sunday/is-it-time-tobreak-up-google.html

Thiel, P. (2014), 'Quotes from Peter Thiel, Zero to One: Notes on Startups, or How to Build a Successful Business, Crown Business', Available at: https://www.goodreads.com/work/quotes/25332940-zero-to-one-notes-on-startups-or-how-to-build-the-future

Thomson, R. (2017), 'News Corp CEO: The Almighty Algorithm: - "fake news" and other consequences of Google, Amazon and Facebook's relentless focus on quantity over quality', 15 June 2017, decries Google's anticompetitive conduct', Available at: http://www.foxnews.com/opinion/2017/06/15/news-corp-ceoalmighty-algorithm-fake-news-and-other-consequences-google-amazon-andfacebooks-relentless-focus-on-quantity-over-quality.html

Times of India (2017), 'Wannacry hits computers in Thiruvananthapuram railway divisional office', Times of India, 24 May 2017, Available at: http://timesofindia.indiatimes.com/city/thiruvananthapuram/wannacry-hitscomputers-in-tpuram-railway-divisional-office/articleshow/58813334.cms 
Transport Intelligence (2016), 'Global e-commerce Logistics: e-commerce Supply Chain Profiles - Alibaba - Fulfilment', Available at: www.ti-insight.com/product/globale-commerce-logistics-2016

Sood, V. (2017), '7 top IT firms lay off 56,000 this year, new tech and Trump's policies blamed', Hindustan Times, 19 July 2017, Available at: http://www.hindustantimes.com/business-news/seven-top-it-firms-to-lay-off-56000-this-year-new-tech-and-trump-s-policies-blamed/storynDPfhZ3taX0WkE3sJotVwM.html

United Nations (UN) General Assembly Human Rights Council (2016), Resolution on the Promotion, Protection and Enjoyment of Human Rights on the Internet, A/HRC/32/L.20, 27 June 2016.

USTR (2016), 'The Digital 2 Dozen', 13 April 2016, Available at: https://ustr.gov/sites/default/files/Digital-2-Dozen-Final.pdf

USTR (2016a), 'Ensuring a free and open Internet', Available at: https://ustr.gov/sites/default/files/TPP-Ensuring-a-Free-and-Open-Internet-FactSheet.pdf

USTR (2016b), 'Ambassador Froman Announced New Digital Trade Working Group', July 2016, Available at: https://ustr.gov/about-us/policy-offices/press-office/pressreleases/2016/july/ambassador-froman-announces-new

Vaughan, L. and G. Finch (2017), 'Libor Scandal: the bankers who fixed the world's most important number', The Guardian, 18 January 2017, Available at:

https://www.theguardian.com/business/2017/jan/18/libor-scandal-the-bankers-whofixed-the-worlds-most-important-number

Waymo (2017), Available at: https://www.google.com/selfdrivingcar/

WTO (1998), The Ministerial Declaration on Global Electronic Commerce adopted on 20 May 1998, WT/MIN(98)/DEC/2.

WTO (1999), Progress Report to General Council, Work Programme on Electronic Commerce, S/L/74, 27 July 1999.

WTO (2001), Guidelines for the Scheduling of Specific Commitments under the General Agreement on Trade in Services, S/L/92, 28 March 2001.

WTO (2002), Communication from the European Communities and their Member States, 'Coverage of CPC 84 - Computer and Related Services', TN/S/W/6, S/CSC/W/35, 24 October 2002.

WTO (2004), Panel Report, US - Gambling, WT/DS285/R, 10 November 2004.

WTO (2009), 'China - Publications and Audiovisual Products', Panel Report, WT/DS363/R, 12 August 2009.

WTO (2016), 'Work Programme on Electronic Commerce. Non-paper from the United States', JOB/GC/94, July 2016.

WTO (2016a), Proposal by Japan and others, 'Reinvigorating Discussions on Electronic Commerce', JOB/GC/96/Rev.1, 14 July 2016.

WTO (2016b) 'Aiming at the $11^{\text {th }}$ Ministerial Conference', November 2016, JOB/GC/110/Rev.1, JOB/CTG/2/Rev.1, JOB/SERV/243/Rev.1, JOB/DEV/39/Rev.1 
WTO (2016c), 'Work Programme on Electronic Commerce. Aiming at the 11th Ministerial Conference. Communication from the People's Republic of China and Pakistan', JOB/GC/110/Rev.1, 16 November 2016.

WTO (2017), Proposal by Japan, 'Possible Way Forward on Electronic Commerce', JOB/GC/130, 14 July 2017.

WTO (2017a), Communication from Canada, Chile, Colombia, Cote d'Ivoire, the European Union, the Republic of Korea, Mexico, Montenegro, Paraguay, Singapore, and Turkey, 'Work Programme on Electronic Commerce. Trade Policy, the WTO, and the Digital Economy', 13 January 2017, JOB/GC/116, JOB/CTG/4, JOB/SERV/248, JOB/IP/21, JOB/DEV/42

WTO (2017b), Communication from the European Union, 'An enabling environment to facilitate online transactions', 23 May 2017, TN/S/W/64

WTO (2017c) Communication from Brunei Darussalam, Colombia, Costa Rica, Hong Kong, China, Israel, Malaysia, Mexico, Nigeria, Pakistan; Panama, Qatar, Seychelles, Singapore and Turkey, 'Electronic Commerce and Development', 14 February 2017, JOB/GC/117, JOB/CTG/5, JOB/SERV/249, JOB/IP/22, $\mathrm{JOB} / \mathrm{DEV} / 43$, revised from July 2016.

WTO (2017d), 'ASEAN Reflections on Lunch Panel on "Can e-Commerce Trade Rules Help MSMEs from Developing Countries' held During the UNCTAD e-Commerce Week, 27 April 2017, JOB/GC/126, 2 June 2017.

WTO (2017e), Communication from Australia, Colombia, the European Union, Japan, Republic of Korea, and Mexico, 'Domestic Regulation - Transparency', JOB/SERV/251, 28 February 2017.

WTO (2017f), Communication from India. 'Trade Facilitation for Services Agreement, S/C/W/372, TN/S/W/63, S/WPDR/W/58, 23 February 2017.

WTO (2017g), Council for Trade in Services. Report of the Meeting held on 16-17 March 2017, S/C/M/130, 6 June 2017. 


\section{ERIA Discussion Paper Series}

\begin{tabular}{|c|c|c|c|}
\hline No. & Author(s) & Title & Year \\
\hline $2017-10$ & Jane KELSEY & $\begin{array}{l}\text { The Risks for ASEAN of New } \\
\text { Mega-Agreements that Promote the } \\
\text { Wrong Model of e-Commerce }\end{array}$ & $\begin{array}{l}\text { Oct } \\
2017\end{array}$ \\
\hline 2017-09 & $\begin{array}{l}\text { Lili Yan ING and Olivier } \\
\text { CADOT }\end{array}$ & $\begin{array}{l}\text { Ad valorem equivalents of non- } \\
\text { tariff measures in ASEAN }\end{array}$ & $\begin{array}{c}\text { Oct } \\
2017\end{array}$ \\
\hline 2017-08 & $\begin{array}{l}\text { Venkatachalam } \\
\text { ANBUMOZHI and } \\
\text { Xianbin YAO }\end{array}$ & $\begin{array}{l}\text { Remaking Energy Policies for } \\
\text { Global Sustainability: The Case of } \\
\text { Flying Geese Model and Path } \\
\text { Dependencies in East Asia }\end{array}$ & $\begin{array}{l}\text { Oct } \\
2017\end{array}$ \\
\hline $2017-07$ & Lurong CHEN & $\begin{array}{l}\text { Globalisation and Trade } \\
\text { Liberalisation in Supporting GVCs } \\
\text { Upgrade: The Case of the Republic } \\
\text { of Korea }\end{array}$ & $\begin{array}{l}\text { Sep } \\
2017\end{array}$ \\
\hline $2017-06$ & Hideo KOBAYASHI & $\begin{array}{l}\text { Current Status and Traits of the } \\
\text { Auto Parts Industry in Viet Nam }\end{array}$ & $\begin{array}{l}\text { Aug } \\
2017\end{array}$ \\
\hline $2017-05$ & Martin SCHRÖDER & $\begin{array}{l}\text { Viet Nam's Automotive Supplier } \\
\text { Industry: Development Prospects } \\
\text { under Conditions of Free Trade and } \\
\text { Global Production Networks }\end{array}$ & $\begin{array}{l}\text { May } \\
2017\end{array}$ \\
\hline $2017-04$ & Eiji YAMAJI & $\begin{array}{l}\text { Assessing the Competitive } \\
\text { Advantage of Public Policy Support } \\
\text { for Supply Chain Resilience }\end{array}$ & $\begin{array}{l}\text { May } \\
2017\end{array}$ \\
\hline $2017-03$ & John K.M. KUWORNU & $\begin{array}{l}\text { Chained to Sustainable } \\
\text { Development Goals? The Changing } \\
\text { Role of Entities for Enhanced } \\
\text { Resilience along Agriculture Food } \\
\text { Value Chains in Thailand }\end{array}$ & $\begin{array}{l}\text { May } \\
2017\end{array}$ \\
\hline $2017-02$ & $\begin{array}{l}\text { Budi Indra SETIAWAN } \\
\text { and Falatehan FAROBY }\end{array}$ & $\begin{array}{l}\text { Peat Policy and Its Implications on } \\
\text { Value Chains of Indonesian Palm } \\
\text { Oil }\end{array}$ & $\begin{array}{l}\text { May } \\
2017\end{array}$ \\
\hline 2017-01 & $\begin{array}{l}\text { Vangimalla R. REDDY } \\
\text { and Venkatachalam } \\
\text { ANBUMOZHI }\end{array}$ & $\begin{array}{l}\text { Managing Stranded Assets and } \\
\text { Protecting Food Value Chain from } \\
\text { Natural Disaster }\end{array}$ & $\begin{array}{l}\text { May } \\
2017\end{array}$ \\
\hline
\end{tabular}

Previous year of ERIA Discussion Paper, can be downloaded at:

http://www.eria.org/publications/discussion_papers/FY2016/

http://www.eria.org/publications/discussion_papers/FY2015/ 
http://www.eria.org/publications/discussion_papers/FY2014/ http://www.eria.org/publications/discussion_papers/FY2013/ http://www.eria.org/publications/discussion_papers/FY2012/ http://www.eria.org/publications/discussion_papers/FY2011/ http://www.eria.org/publications/discussion_papers/FY2010/ http://www.eria.org/publications/discussion_papers/FY2009/ http://www.eria.org/publications/discussion papers/FY2008/ 